NBER WORKING PAPER SERIES

\title{
COORDINATED NOISE TRADING: EVIDENCE FROM PENSION FUND REALLOCATIONS
}

\author{
Zhi Da \\ Borja Larrain \\ Clemens Sialm \\ José Tessada \\ Working Paper 22161 \\ http://www.nber.org/papers/w22161
}

We thank Patricio Ayala, Tomás Balmaceda, Keith Brown, Yong Chen (Gutmann Symposium discussant), Nicolás Desormeaux, David Hirshleifer, Paul Hsu, Jennifer Huang, Gabriele LaSpada, Dong Lou (EFA discussant), Katya Malinova (University of Toronto discussant), Gonzalo Maturana, Pamela Searle, René Selpúlveda, Tao Shu (ABFER discussant), Rick Sias (AFA discussant), David Solomon (FinanceUC discussant), Laura Starks, Zheng Sun, Sheridan Titman, Chuck Trzcinka (UC Davis discussant), Jay Wang (CICF discussant), Yan Xu and seminar participants at the Cheung Kong Graduate School of Business, the Federal Reserve Bank of New York, Georgia State University, Hong Kong University of Science and Technology, Peking University, Tsinghua University, the University of California at Irvine, the University of Hong Kong, the University of Missouri, the University of Notre Dame, the University of Texas at Austin, York University, the 9th International FinanceUC Conference in Chile, the 2015 Conference on Liquidity Risk in Asset Management at the University of Toronto, the 2015 Conference of the Asian Bureau of Finance and Economic Research, the 2015 China International Conference in Finance, the 2015 Meetings of the European Finance Association, the 2015 WU Gutmann Center Symposium, the 2015 University of California at Davis Finance Symposium, and the 2016 Meetings of the American Finance Association for comments and suggestions. We thank Daniel Muñoz and Cristián Rojas for excellent research assistance. Da acknowledges the generous support from the Andrónico Luksic Grants program at the University of Notre Dame. Larrain acknowledges funding from Proyecto Fondecyt Regular \#1141161. Tessada acknowledges financial support from Conicyt Proyecto Inserción a la Academia \#79100017. Larraín is an academic advisor to Larrain Vial Wealth Management. Sialm is an independent contractor with AQR Capital Management. All errors are our own. The views expressed herein are those of the authors and do not necessarily reflect the views of the National Bureau of Economic Research.

At least one co-author has disclosed a financial relationship of potential relevance for this research. Further information is available online at http://www.nber.org/papers/w22161.ack

NBER working papers are circulated for discussion and comment purposes. They have not been peer-reviewed or been subject to the review by the NBER Board of Directors that accompanies official NBER publications.

(C) 2016 by Zhi Da, Borja Larrain, Clemens Sialm, and José Tessada. All rights reserved. Short sections of text, not to exceed two paragraphs, may be quoted without explicit permission provided that full credit, including $(\subset$ notice, is given to the source. 
Coordinated Noise Trading: Evidence from Pension Fund Reallocations

Zhi Da, Borja Larrain, Clemens Sialm, and José Tessada

NBER Working Paper No. 22161

April 2016

JEL No. F32,G02,G11,G12,G14,G15,G18,G23,G28,H31,H55

\begin{abstract}
$\underline{\text { ABSTRACT }}$
We document a novel channel through which coordinated noise trading exerts externalities on financial markets dominated by institutional investors. We exploit a unique set of events where Chilean pension fund investors followed an influential financial advisory firm that recommended frequent switches between equity and bond funds. The recommendations, which mostly followed short-term trends, generated large and coordinated fund flows. These flows resulted in substantial price pressure and increased volatility in financial markets. Pension funds increased cash holdings as a response. Our findings suggest that giving retirement savers unconstrained reallocation opportunities may exert negative externalities on financial markets.
\end{abstract}

Zhi Da

University of Notre Dame 239 Mendoza College of Business

Notre Dame, Indiana 46556-5646

zda@nd.edu

Borja Larrain

Escuela de Administracion

Pontificia Universidad Catolica de Chile

Avda Vicuna Mackenna 4860

Macul, Santiago

Chile

borja_larrain@yahoo.com
Clemens Sialm

University of Texas at Austin

McCombs School of Business

2110 Speedway; B6600

Austin, TX 78712-1276

and NBER

clemens.sialm@mccombs.utexas.edu

José Tessada

Escuela de Administracion

Pontificia Universidad Catolica de Chile

Avda Vicuna Mackenna 4860

Macul, Santiago

Chile

jtessada@gmail.com 


\section{Introduction}

The impact of noise traders on asset prices is central to the debate over market efficiency. Black (1986) points out in his AFA presidential address that noise might cause market inefficiencies. DeLong, Shleifer, Summers, and Waldmann (1990a) formalize the role of noise traders in financial markets. They show that noise traders can create mispricing and excess volatility if the trading horizon of risk-averse arbitrageurs is short. Taking advantage of several unique features of the Chilean pension system, we document a novel channel through which coordinated noise trading can exert large price pressure in financial markets, even when asset ownership is dominated by institutional investors.

The Chilean pension system is a fully-funded defined-contribution (DC) pension system with personal retirement accounts. ${ }^{1}$ Investors can freely allocate their balances across funds with different risk levels. A financial advisory firm called "Felices y Forrados" (FyF, translated as "Happy and Loaded") started in 2011 to cater to the demand of individual investors to time the market. For a fee of around US\$20 per year, FyF sends investors their switching recommendations by e-mail or private website login. FyF gained popularity among Chilean pension investors through an aggressive marketing campaign on social media. As a result, recommendations from $\mathrm{FyF}$ act as a coordination device among noise traders. This is evident from Figure 1, which shows the number of voluntary daily fund switches since 2011. The spikes in the number of account switches closely coincide with FyF recommendations. These account switches involve large fund flows, amounting from US\$1 to US\$5 billion and corresponding to between $10 \%$ and $20 \%$ of funds' assets.

We document a large aggregate price impact immediately after the reallocation recommendations become public. The price pressure in the equity market amounts to around $1 \%$ during the first day after the FyF recommendation and reverts after a couple of weeks. The

\footnotetext{
${ }^{1}$ The Chilean pension system has obtained substantial attention in economics and finance research over the last decades due to its early adoption of personal retirement accounts. See, for example, Diamond and Valdés-Prieto (1994), Diamond (1996), Mitchell and Barreto (1997), Edwards (1998), Benartzi and Thaler (2001), Mitchell, Todd, and Bravo (2009), and Opazo, Raddatz, and Schmukler (2014) for a discussion of the Chilean experience.
} 
price pressure is accompanied by abnormal turnover induced by the switches. The price pressure pattern that we document is remarkably consistent with the prediction of DeLong, Shleifer, Summers, and Waldmann (1990b). The first day effect implies an elasticity of demand for stocks of -0.45 , which means that demand is more inelastic than the one estimated in the case of index additions by Shleifer (1986) and Wurgler and Zhuravskaya (2002). Placebo tests and additional robustness tests confirm that the price pressure is more likely driven by recommendation-based fund reallocations rather than from fundamental factors that may trigger the recommendations in the first place.

Besides the aggregate price effects we also find significant cross-sectional differences in the impact of the recommendations. The price pressure in the equity market is driven by relatively large stocks that dominate the portfolios of pension funds. Smaller stocks, on the other hand, are not traded as frequently as they are more illiquid and amount to a smaller fraction of funds' holdings. More generally, consistent with the findings in Greenwood and Thesmar (2011), the prediction in the cross-section is that stocks that receive higher portfolio weights (relative to their market capitalization) at the time of the recommendations will experience greater price pressure and excess volatility. We show that this is the case using monthly panel regressions after controlling for other stock characteristics.

Stambaugh (2014) documents that there has been a substantial decline in direct individual equity ownership in the U.S. Thus, it has been suggested that noise trading, which is driven primarily by individual investors, might become less pronounced as individuals reduce their direct stock ownership. However, the evidence in our paper suggests that noise traders can affect asset prices even when these assets are held primarily by large financial institutions. As Frazzini and Lamont (2008) argue, "it is hard for a fund manager to be smarter than his clients. Mutual fund holdings and performance are driven by both managerial choices in picking stocks and retail investor choices in picking managers." Such fund choices could be affected by "noise." For example, Da, Engelberg, and Gao (2015) show that an investor sentiment measure based on internet search results can predict daily mutual 
fund flows between equity and bond funds.

Our paper is also related to the large literature that documents the impact of fund flows on stock returns. Edelen (1999), Coval and Stafford (2007), Frazzini and Lamont (2008), and Lou (2012) document persistent price pressure from fund flows. Whereas mutual funds flows are often driven by crises periods or by other extreme events, the frequent recommendation changes in Chile are less likely contaminated by fundamental determinants, offering us a cleaner setting to study price pressure. Chen, Goldstein, and Jiang (2010) provide empirical evidence that strategic complementarities among mutual fund investors generate fragility in financial markets. Our paper suggests that participants in the Chilean pension system might have an incentive to switch their investment allocations if they expect that other participants will switch based on these recommendations.

Our results suggest that noise traders can still leave sizeable footprints in financial markets when coordinated through social media. In this regard, our paper also contributes to the literature on media, investor attention, and the origins of investor sentiment. ${ }^{2}$ By considering the effect of retail investors on fund inflows and outflows, we show that retail attention can result in both positive and negative price pressure.

Our paper also speaks to the growing literature that studies the effects of financial advice on investor behavior. ${ }^{3}$ While most of the literature has focused on the role of advisors in debiasing and improving financial decision making by individual investors, we explore the case of a financial advisor that caters to investors' preferences and biases. Our paper shows that financial advisors can impact aggregate returns and turnover by sending simultaneous advice to a large population of investors, which triggers coordinated portfolio switches and

\footnotetext{
${ }^{2}$ See Shleifer and Summers (1990), Sias (2004), Baker and Wurgler (2006), Kogan, Ross, Wang and Westerfield (2006, 2009), Tetlock (2007), Barber and Odean (2008), Cohen and Frazzini (2008), Corwin and Coughenour (2008), Fang and Peress (2009), Loughran and McDonald (2011), Da, Engelberg and Gao (2011), Engelberg and Parsons (2011), Gurun and Butler (2012), DeValut, Sias, and Starks (2014), Greenwood and Shleifer (2014), Peress (2014), Peress and Schmidt (2014), among others.

${ }^{3}$ See, for example, Lusardi and Mitchell (2007), Bergstresser, Chalmers, and Tufano (2009), Bhattacharya et al. (2012), Inderst and Ottaviani (2012a, 2012b), Mullainathan, Nöth, and Schoar (2012), Christoffersen, Evans, and Musto (2013), Chalmers and Reuter (2015), Foerster et al. (2015), Gennaioli, Shleifer, and Vishny (2015), and Von Gaudecker (2015).
} 
reallocations.

Finally, our findings have important implications for the optimal design of pension systems. The literature on DC pension plans has documented that participants are often inert, follow default investment options, and are subject to behavioral biases. ${ }^{4}$ Our paper documents that while there are good reasons for re-balancing retirement portfolios (e.g., life cycle dynamics, changes in risk tolerance, changes in market environments), investors can also harm themselves and others if portfolio reallocations are too frequent. Indeed, as a response to these frequent fund switches, pension funds in Chile in the past years have significantly reduced their holdings of less liquid securities and replaced them with cash. An increase in the proportion of highly liquid securities might not be optimal for retirement investors who typically have long-term investment horizons. The flexibility of investing in different funds could actually contribute to a classical limits of arbitrage argument (Shleifer and Vishny 1997), consistent with the insight from Stein (2005) about the design of the open-ended fund structure.

The rest of the paper is organized as follows. In Section 2, we give background information on the Chilean pension system and the FyF recommendations. In Section 3 we provide evidence that the recommendations have a significant impact on fund flows. Section 4 presents the main results on aggregate and cross-sectional price pressure. Section 5 discusses the reactions of pension plans to the FyF recommendations. We conclude in Section 6 .

\section{Institutional Background}

We describe in this section the Chilean pension fund system, the Chilean financial advisory firm Felices y Forrados and sources of data used in our study.

\footnotetext{
${ }^{4}$ Benartzi and Thaler (2001), Madrian and Shea (2001), Choi et al. (2002, 2004), Agnew, Balduzzi, and Sunden (2003), Huberman and Jiang (2006), Elton, Gruber, and Blake (2006, 2007), Brown, Liang, and Weisbenner (2007), Cohen and Schmidt (2009), Christoffersen and Simutin (2014), Sialm, Starks, and Zhang (2015), and Pool, Sialm, and Stefanescu (2015) discuss the structure of pension plans and the behavior of participants and administrators.
} 


\subsection{Chilean Pension Funds}

The Chilean pension system was privatized in 1980 through the creation of a DC pension fund system that replaced the public pay-as-you-go system. All workers have to contribute $10 \%$ of their taxable income to individual retirement accounts. This obligation to contribute does not apply to incomes above a threshold of approximately US\$3,000 per month. The pension system has between 9 and 10 million participants over our sample period 2011-2014. The average investor in the system is 38 years old and has average pension savings of around US $\$ 50,000 .^{5}$

The pension fund industry has been instrumental for the development of the local financial market. During the period from 2011 to 2014 the assets of the pension system amounted to around US $\$ 150$ billion on average, which represented approximately $60 \%$ of Chilean GDP. Pension funds have accumulated a sizeable investment in the local equity and fixed income markets. Close to $30 \%$ of the Chilean stock market free float and $30 \%$ of the Chilean government bond market are held by pension funds. Pension fund administrators (AFPs from their acronym in Spanish) charge a fee out of the contributions of the participants. Prior to 2008 they also charged a small maintenance fee per participant.

Since 2002, workers can choose between five types of funds that each AFP is legally bound to offer. These five funds (A through E) cater to different risk preferences of investors. Current legislation also allows investors to split their pension savings between funds but not between AFPs. As reported in Panel A of Table 1, fund A has the largest share of equities among the five funds and is considered the riskiest fund. Fund $\mathrm{E}$ is almost entirely invested in domestic fixed income securities. Funds B, C, and D also are age-dependent default funds. Investors are automatically shifted to less risky funds as they get older, unless they have explicitly expressed their preference for other funds. Funds A and E are not default options

\footnotetext{
${ }^{5}$ Average income in Chile amounts to around US $\$ 2,000$ per month, which turns into an average pension savings of US $\$ 50,000$ given a contribution rate of $10 \%$ and an accumulation period of $15-20$ years for a 38 -year old saver. This number corresponds to the entire pension savings of most investors in our sample given that broad-based social security payments do not exist in Chile.
} 
and have to be actively chosen by investors. The largest fund is fund $\mathrm{C}$, which accounts for close to $40 \%$ of the assets in the pension fund system. Fund C was the only available fund prior to 2002, which partially explains its relatively large size. Fund A accounts for approximately $20 \%$ of assets, similar to fund B, while funds D and E account for less than $15 \%$ and $10 \%$, respectively.

The five types of funds are subject to different legal limits. For example, equity (domestic plus international) has to represent between $40 \%$ and $80 \%$ of fund A, between $25 \%$ and $60 \%$ of fund B, and so on. The relative order has to be preserved at all times (i.e., fund A has to invest more in equities than fund B, fund B more than fund C, etc.). This ensures that the investment becomes less risky as we move from fund A to fund E. There are also limits regarding the fraction of foreign assets that pension funds are allowed to hold. Investors in funds $\mathrm{A}$ and $\mathrm{B}$ are more frequently young (under 30), investors in fund $\mathrm{C}$ are primarily middle-aged (between 30 and 55), and investors in funds D and E are more frequently older people (above 55). Interestingly, male investors are over-represented in the extreme portfolios, which are actively selected.

Our paper focuses primarily on Chilean domestic equities and government bonds, which are affected by the switches between funds A and E. Panel A of Table 1 documents that fund $\mathrm{A}$ holds more domestic equity than fund $\mathrm{E}$ (16.9\% vs. 1.1\%) while fund $\mathrm{E}$ holds more domestic bonds than fund A (80.1\% vs. 9.0\%). Panel B of Table 1 gives a recent snapshot of the holdings of domestic equity and government bonds in funds A and E. Panel B suggests that the domestic equity positions are dominated by large stocks. For example, the largest ten stocks account for around half of the domestic equity portfolio. The average time to maturity of the government bond portfolio is more than ten years, suggesting that fund $\mathrm{E}$ holds longer-term government bonds than the market (average maturity of 8.7 years).

The multi-fund system is designed to make it easy for investors to tailor retirement portfolios to their risk preferences. Indeed, investors can freely choose a fund for their current and future savings, as well as transfer their accumulated pension savings between 
funds. Investors can submit a switching request on any day. Requests submitted before midnight are recorded on the corresponding day even if the switching request was sent after business hours. Once a switching request is submitted, the portfolio change is effective four business days after the initial submission, a delay that was established to determine if the switching request contained clerical errors. ${ }^{6}$ The transaction prices for the switches are based on the prices on the second day after the request was submitted by the investor. For example, an investor submitting on day $t$ a request to switch between funds $\mathrm{A}$ and $\mathrm{E}$, and who owns $N^{A}$ shares of fund $\mathrm{A}$, will receive on day $t+4$ shares of fund $\mathrm{E}$ equal to $N^{A}$ times the ratio of the prices of $\mathrm{A}$ and $\mathrm{E}$ on the second day after the switching request was submitted. Thus, the number of shares of fund E obtained in the switching transaction amounts to: $N^{E}=N^{A} p_{t+2}^{A} / p_{t+2}^{E}$.

In order to avoid large and abrupt changes, the regulator has established that switches cannot exceed $5 \%$ of the fund assets on a single day. If the requested switches exceed that amount either for inflows or outflows, then the fund has to postpone the switches following a first-come first-served rule until all switches have been executed. Thus, a $20 \%$ redemption request would delay the execution of late submitters by up to four days.

The pension fund industry is regulated by the Superintendencia de AFPs (SAFP). The SAFP's mandate includes watching over investment limits, making sure that information is disclosed to investors, and other administrative and oversight tasks. Chilean law sets penalties for funds that perform poorly with respect to the average of their peers. This is implemented by establishing a minimum yield that is equal to the previous three-year return of the average fund in each category (A through E) less a few percentage points defined by law. Together with other forces that lead to herding among fund managers, such as competition and career concerns (see for example Scharfstein and Stein, 1990), these penalties provide incentives for managers not to deviate too much from the investment decisions of other pension fund managers (Raddatz and Schmukler, 2013). In practice, penalties for

\footnotetext{
${ }^{6}$ For this reason, when we examine the impact of FyF recommendations on monthly fund flows, we line up FyF recommendations on the last three days of a month with fund flows in the following month.
} 
violating the minimum yield rule have never been imposed since 1998. Given the portfolio restrictions and incentives for pension funds, all of their portfolios mimic each other quite closely. In other words, there is not much cross-sectional variation in fund portfolios.

\subsection{Felices y Forrados}

"Felices y Forrados" (FyF in short; translated as "Happy and Loaded") is an financial advisory firm that started to operate in $2011 .{ }^{7}$ As can be seen on their website, FyF position themselves as outsiders to the financial system, catering to a relatively young audience. FyF offers a simple market timing strategy for pension fund investors. Investors receive a recommendation to switch between various funds through email or website login. The recommendations are accompanied by little explanations or market analyzes. FyF does not recommend different AFPs, they just make recommendations about fund types. They charge a fee that is equivalent to roughly US\$20 per year. Table 2 provides a complete list of their recommendations up to March 2015. For most of our analysis we focus on the first 15 recommendations that involve only funds A and E. If many investors follow their recommendations, we predict negative (positive) price pressure on stocks (bonds) when the recommendation is to move from fund $\mathrm{A}$ to fund $\mathrm{E}$.

The time series of the daily number of switching requests in Figure 1 displays many spikes that can be largely associated with the recommendations from FyF immediately preceding them. ${ }^{8}$ Indeed, the last seven recommendations from FyF all triggered at least 10,000 switches between funds on the next few days. ${ }^{9}$ The number of switches often remains high

\footnotetext{
${ }^{7}$ The firm's website is http://www.felicesyforrados.cl. Note that FyF recently started a second website (http://www.happyandloaded.cl) that does not offer the same advice or service the original Spanish site offers. It is focused on voluntary savings and mutual funds. There exist other services similar to FyF, however they are significantly less well-known and have not achieved the notoriety of FyF, both in the news and in social media. Some other financial advisors are Fondo Alerta (Fund Alert), Previsionarte (mixing the Spanish words for retirement savings, prevision and art), and Tiempo Para Ganar (Time to Win).

${ }^{8}$ This figure was provided to us by the Chilean pension regulator. We do not have access to the underlying data of switches at a daily frequency.

${ }^{9}$ According to their own FAQ and online help, FyF issues switching recommendation after the market closes. As a result, most actual switching requests are placed after the recommendation date. More recently, $\mathrm{FyF}$ occasionally warns investors about potential recommendations changes using a traffic-light system.
} 
for a few additional days, potentially due to inertia or word of mouth effects as these recommendations are passed along from FyF subscribers to non-subscribers. The power of FyF recommendations as a coordination device among pension investors is especially strong starting from the fifth recommendation in early 2012, when FyF began to attract investor attention by appearing on various social media. ${ }^{10}$ The Google Search Volume Index (SVI) in Panel A of Figure 2 confirms this pattern. Google only started to track "Felices y Forrados" after their fourth recommendation. ${ }^{11}$

We also note that not all spikes in switching requests in Figure 1 are accompanied by FyF recommendations. The volatile equity market in 2008 prompted many investors to attempt to "time" the market. The fear of 2008 repeating likely caused switches from fund A to E every time there was a large drop in the equity market, explaining a few other spikes in fund switching requests. For example, the spike in March 2011 followed a large drop in the Chilean equity index.

Data on switching requests by fund type are only available at a monthly frequency. Panel $\mathrm{B}$ of Figure 2 plots the monthly number of switches from funds $\mathrm{E}$ to $\mathrm{A}$ (positive) and from A to $\mathrm{E}$ (negative). The plot confirms that the fund switches are consistent with the timing of FyF recommendations.

While we do not observe the exact formula used by FyF for making their recommendations, the analysis in Table 3 suggests that FyF follows a short-term trend-chasing strategy. We estimate two separate logit models to account for the two types of switches. In columns (1) to (3) (columns (4) to (6)), the dependent variable takes the value of one if a recommendation to switch to fund A (E) is issued that day, conditional on fund $\mathrm{E}$ (A) being the currently recommended fund. The explanatory variables are lagged stock and government bond returns, lagged exchange rate changes, and lagged inflation. The models are These warnings could motivate some traders to switch prior to the official recommendation dates.

${ }^{10}$ For example, the FyF LinkedIn profile was created on September 27, 2011 and the FyF Twitter account was created in January 2012. The oldest pictures on their Facebook page are dated March 2012.

${ }^{11}$ The spike in Google Search Volume in June 2013 is explained by a report published by the local regulator of pension funds (SAFP) against FyF. 
estimated with a penalized maximum likelihood estimator because of the low prevalence of the outcome. The pseudo $R^{2}$ is calculated following an analog of McFadden's pseudo $R^{2}$ $\left(1-\frac{\ln \text { Likelihood }_{\text {full }}}{\ln \text { Likelihood }_{\text {restricted }}}\right)$, where the full model is the specification presented in each column and the restricted model is the same specification with the constraint that all coefficients except the constant are equal to zero, using the penalized log likelihood.

We find evidence that when the Chilean stock (government bond) market has experienced good returns during the most recent week, $\mathrm{FyF}$ is more likely to recommend switching from fund $\mathrm{E}$ to $\mathrm{A}$ (A to $\mathrm{E}$ ). In addition, exchange rate fluctuations are also helpful in explaining a switch to fund E. The overall goodness of fit of the models in Table 3 (i.e., the Pseudo $R^{2}$ ) is low, however, suggesting that it is hard to associate FyF's recommendations with market data or fundamentals. Given their reliance on past returns one would not expect the FyF strategy to generate alpha when financial markets are at least weak-form efficient. To alleviate the concern that fundamental variables that drive FyF's recommendations also drive future returns, our subsequent analysis controls for these and other fundamental variables when predicting returns. ${ }^{12}$

Another way to evaluate the informativeness of FyF is to study whether investors actually made money by following these recommendations. We examine this question by considering the following three investment strategies: (1) Buy-and-hold fund A (Fund A); (2) Buy-and-hold fund E (Fund E); and (3) Switching between fund A and E following FyF's recommendations $(\mathrm{FyF}) .{ }^{13}$ For strategy (3) we assume that the switching request is submitted immediately following the recommendation after the market closes on day $t$, and thus will be implemented at the closing prices of day $t+2$, as discussed previously in Section 2.1.

The average cumulative returns of the three strategies are plotted in Figure 3. The top

\footnotetext{
${ }^{12}$ We have also included in unreported results the Google search volume in the prior week, the return on day zero, and the turnover on day zero. Including these additional controls does not affect the results meaningfully.

${ }^{13}$ Recall that there are six pension companies (AFPs) during our sample period, each offering funds A to E. As such, we first compute cumulative returns to the three strategies for each AFP and then average the returns across the six AFPs to obtain the average cumulative returns to following the three strategies. The returns on the same fund across different AFPs are very similar, again due to incentives set up by the regulator and market forces that generate herding.
} 
panel shows the cumulative returns of investments of $\$ 1$ in each strategy starting from the first FyF recommendation on July 27, 2011. Indeed, Figure 3 shows that FyF's "market timing" strategy outperforms both fund A and E by March 2014. The cumulative return is $15.8 \%$ for fund A, $21.0 \%$ for fund E, and $26.5 \%$ for FyF. Furthermore, the FyF strategy almost always exhibits a higher return than the other two passive strategies. This is the figure that is prominently displayed in FyF's marketing material. It is not surprising that, when presented with such an attractive track record, an average investor might be tempted to follow FyF.

Nevertheless, returns in the top panel are misleading to an average investor since very few of them paid attention to FyF before January 2012, as documented in Figure 2. In addition, FyF became popular because the first recommendation turned out to be very profitable as it preceded a significant decline in the stock market. If we consider a "tradable" strategy where one starts investing from the fifth recommendation on March 29, 2012, then the FyF strategy underperforms both funds A and E.

The above analysis suggests that the recommendations from $\mathrm{FyF}$ are unlikely to be informative. The correlated trading triggered by their recommendations is more likely reflecting noise trading rather than fundamental trading.

\subsection{Data Sources}

Data used in this paper come from various sources. The SAFP makes data on pension funds available to the public on its website (http://www.safp.cl). The website reports daily share values for all funds, and monthly portfolio holdings, demographics of investors, and assets under management. We can compute monthly money flows from public data, but not at the daily level. ${ }^{14}$ We also collect data on prices, trading volume, and accounting variables (e.g., book value of equity) for domestic stocks from the website of Santiago's Stock Exchange (http://www.bolsadesantiago.com/) and Economatica. The fixed in-

\footnotetext{
${ }^{14}$ Money flows are computed as Flow $_{t}=A U M_{t}-\left(1+R_{t}\right) A U M_{t-1}$, where $A U M$ is the assets under management of a given fund and $R$ is the monthly return according to the per share value of the fund.
} 
come data are taken from LVA Indices (http://www.lvaindices.com), a provider of fixed income indices in Latin America (the Dow Jones LATixx indices). All information about the recommendations, including dates and funds, are taken from Felices y Forrados website (http://www.felicesyforrados.cl). Exchange rate data was downloaded from the Central Bank of Chile's online database (http://www.bcentral.cl). Finally, the MSCI World Index, MXWO, is obtained from the MSCI website (https://www.msci.com/resources/factsheets/ index_fact_sheet/msci-world-index.pdf).

\section{Pension Fund Flows}

To obtain an idea of the magnitude of correlated trading we depict in Figure 4 the monthly net dollar flows of funds A and E from 2003 when we first observe the monthly flow data. All numbers are converted to US dollars and measured in millions. Figure 4 shows very

few switches between funds $\mathrm{A}$ and $\mathrm{E}$ prior to 2008. We observe a flight-to-quality episode as investors pulled out money from fund $\mathrm{A}$ and invested in fund E during the financial crisis of 2008. As the market started to recover in 2009, we observe some flow reversals. The magnitude of these flows, however, is small compared to the large spikes after FyF became popular.

After 2011, we observe large flows to funds A and E that are almost mirror images of each other, coinciding with the FyF recommendations. These large flows are likely reflecting the coordinated noise trading triggered by FyF recommendations. Indeed, a FyF recommendation dummy can explain more than $27 \%$ of the variation in these flows post-2011 with a $t$-statistic of 3.24. The magnitude of the flows is often on the order of US\$1 to US\$4 billion. Recall from Table 1 that the sizes of funds A and E are only US $\$ 28$ billion and US $\$ 14.1$ billion, respectively. In other words, to implement the switches, the pension managers often have to trade $10 \%$ of their entire equity portfolio and $20 \%$ of their entire bond portfolio within a few days. Note that these monthly flows may potentially underestimate 
the correlated noise trading triggered by FyF's recommendation since FyF can make two recommendations in the same month (for example, in June 2012). As consecutive switches are in opposite directions, their effects can offset each other and may not leave a large footprint in the monthly fund flow data.

These fund flows appear even larger when compared to the average turnover in the Chilean equity market. For example, if funds trade their positions proportionally, then a US $\$ 2,500$ million flow implies the need to trade $\$ 2,500 \times(16.9 \%-1.1 \%)=\$ 395$ million worth of domestic equity. ${ }^{15}$ For comparison, the daily turnover in the Chilean equity market amounts to only $\$ 205$ million. Not surprisingly, these trades, if forced to be implemented in a few days, can exert large price pressure.

Younger investors might be more likely to be affected by FyF's recommendations given FyF's marketing strategy based on the internet and social media. One pension fund administrator called Modelo has an investor base that is heavily tilted towards younger investors (see Panel A of Table 4). In fact, in this sample period the average age of Modelo's investors is 24 compared to a system-wide average of 38. Most of Modelo's investors are young, because Modelo won the first auction to allocate new labor market participants to pension fund providers in 2010. Young investors have to stay with Modelo for at least two years, and then they are free to move. Given the young investor base we expect the flows to Modelo to be more sensitive to FyF's recommendations. In Panel B of Table 4 we regress the monthly flows to pension funds (as fraction of assets under management for each fund) on dummy variables for months with a recommendation to switch between funds $\mathrm{A}$ and $\mathrm{E}$. We then interact these dummy variables with an indicator variable for AFP Modelo. We control for lagged returns and flows of the same funds, plus AFP fixed effects.

We find that $\mathrm{FyF}$ recommendations to switch to fund $\mathrm{A}$ are associated with an average positive flow of $4.0 \%$ to fund A, while the flow to Modelo's fund A is further increased by 7.8\%. The coefficients on the regression with flows to fund E are similar, but not necessarily

\footnotetext{
${ }^{15}$ The weights of Chilean stocks in funds $\mathrm{A}$ and $\mathrm{E}$ amount to $16.9 \%$ and $1.1 \%$ based on Panel A of Table 1.
} 
of the same magnitude since funds A and E differ in size. Still, Modelo's fund E suffers larger outflows than other providers $(7.2 \%$ higher $)$ when FyF recommends switching towards fund A. FyF's recommendations to switch to fund E are associated with an average outflow from fund A of 3.7\%, while the outflow from Modelo's fund A is $10.5 \%$ higher. The recommendations to switch to fund $\mathrm{E}$ are associated with an average flow towards fund $\mathrm{E}$ of $16.3 \%$, while the flow to Modelo is $5.3 \%$ higher (although not statistically significant). Overall, Modelo's flows are more volatile in months with FyF recommendations, as one would expect from a fund with a younger investor base.

\section{Price Pressure}

The evidence summarized in the previous section suggests that FyF recommendations, while containing little fundamental information, trigger large pension fund reallocations that reflect coordinated noise trading. These fund reallocations correspond to heavy trading volume, two to five times the average daily volume in the Chilean equity market. In this section, we focus on the price pressure generated by such trading activities.

\subsection{Price Pressure in Event Studies}

Figure 5 contains event-window plots of cumulative adjusted returns and $90 \%$ confidence bands for the Chilean equity market after the FyF recommendations. The adjusted returns are computed by subtracting the returns of the MSCI world market index measured in Chilean pesos from the returns of Santiago's stock exchange selective equity index (IPSA). Event day zero corresponds to the date when FyF sends out its switching recommendation. We consider an event window of 15 trading days since FyF sometimes issue two opposite recommendations within a short period and their effects may net out if the event window is too long. We average cumulative returns across the first 15 recommendations, which involve exclusively funds $\mathrm{A}$ and $\mathrm{E}$ (see Table 2). If the recommendation is to switch from fund $\mathrm{E}$ 
to $\mathrm{A}$, we use the adjusted return. If the recommendation is to switch from fund $\mathrm{A}$ to $\mathrm{E}$, we reverse the sign on the adjusted returns. After this adjustment, stocks are predicted to receive positive price pressure after a recommendation. This allows us to average the returns across the different recommendations to give an estimate of the average magnitude of the price pressure.

Figure 5 displays evidence for price pressure in the direction of FyF's recommendation. The Chilean stock market reacts immediately by around $1 \%$ following FyF's recommendations. The adjusted return remains relatively stable for the subsequent eight days and reverts completely within 15 days. The cumulative adjusted returns are statistically significantly different from zero at a one percent level for the first couple of days (see Table 5). The price pressure does not revert immediately probably due to the fact that switching requests persist for several days, as shown in Figure 1, and since pension managers might delay the implementation of the trades for several days. The eventual price reversal confirms that the initial price pressure is not driven by fundamentals or information. ${ }^{16}$

Interestingly, we also find a significant price impact of $0.64 \%$ in the day prior to the recommendations. This price impact might be due to the fact that some market participants learn about the imminent recommendation changes. ${ }^{17}$ Including the price changes prior to the publication of the recommendations would further increase the overall estimated price pressure. However, we exclude in our estimations the price pressure that occurs prior to the publication of the FyF recommendations, since these price changes might actually trigger the recommendations, as we illustrated in Table 3.

\footnotetext{
${ }^{16}$ If we do not adjust for the MSCI world market index we also find a significant price effect of $0.63 \%$ on the first day after the recommendation. We also observe for raw returns a significant price pressure on the eighth day after the recommendations. This additional price pressure is partly driven by the very poor world-wide stock performance on the eighth day following the first recommendation by FyF (August 8th, 2011). Specifically, the return on the Chilean index on this day was $-6.92 \%$ and the corresponding return on the MSCI world index (in Chilean pesos) was $-4.60 \%$. Since this extreme return is unlikely driven by FyF's recommendation, we adjust the returns for the MSCI world index.

${ }^{17}$ One potential way how market participants might learn about future recommendations is due to warnings that FyF publish on their website using a traffic light system. A yellow light indicates that recommendations are currently being reviewed and might change in the near future. The traffic light system was only introduced in the second half of our sample.
} 
To determine the economic significance of the price pressure, we provide a back of the envelope calculation of the demand elasticities following Wurgler and Zhuravskaya (2002). The demand elasticity is defined as the percentage change in the quantity demanded divided by the percentage change in the price. The percentage change in the price on the first day of trading equals $1.06 \%$, as shown in Table 5 . On the other hand, the percentage change in the quantity demanded can be computed based on the average flows from pension investors of US $\$ 2$ billion, the proportion of Chilean stocks in fund A of $16.9 \%$, and an average free float of the Chilean stock market of US $\$ 70$ billion. Thus, the percentage change in the quantity demanded can be estimated as $\Delta \% q=(2 \times 17 \%) / 70=0.48 \%$. Hence, the one-day elasticity is $-\Delta \% q / \Delta \% p=-0.48 / 1.06=-0.45$. The demand for stocks that we estimate is more inelastic than those estimated with index additions in the US market. For instance, Shleifer (1986) finds an elasticity of -1 , while Wurgler and Zhuravskaya (2002) report elasticities between -5 and -11 .

Table 5 also summarizes the cumulative returns for the Chilean government bond market. The government bond market return is measured using the "Dow Jones LATixx Chile Government Bond Index" which is a total return index. The price impact in the government bond market tends to be consistent with the equity market. However, the economic magnitude is smaller and the price impact is generally not statistically significant. The average cumulative return persists for a longer period and reaches -33 basis points on day 11 (significant at the $10 \%$ level). The reaction of bond prices to recommendation changes may be more muted since the bond funds can hold a larger proportion of cash than the equity funds without substantially increasing their tracking errors. Indeed, Table 1 documents that fund A on average holds only $2.9 \%$ of cash, whereas fund E holds $16.4 \%$ of cash. The larger cash buffer of fund $\mathrm{E}$ enables it to accommodate large fund flows without extensive transactions in less liquid bond securities. Furthermore, the higher persistence in the government bond market might be due to infrequent trading of bonds in the bond index. 


\subsection{Placebo Tests}

To ensure that these price pressure patterns are not driven by fundamentals that trigger the FyF recommendation in the first place, we consider the following placebo test in Table 5. We select placebo dates during a similar 33-month period from July 2003 to March 2006, which coincides with the starting year of our data.

The placebo events are identified using a probit model where the dependent variable takes the value of one if the recommended fund is fund A and zero if it is fund E. ${ }^{18}$ The explanatory variables in the probit model are lagged returns of stocks and government bonds and fundamentals such as exchange rates changes and inflation. The probit model is estimated in-sample during the period from July 2011 to March 2014 and we then compute the out-ofsample probability of FyF recommending fund A or fund E. Starting from a recommendation to hold fund A, we assume that a change to fund E occurs whenever the probability decreases below $25 \%$. If fund $\mathrm{E}$ is being recommended, we assume a change to fund A occurs whenever the probability increases above $75 \%$. This method identifies a total of 17 events during the pre-FyF period.

In contrast to the actual recommendation dates, we do not see any significant price pressure patterns in either the equity market or in the bond market when these placebo dates are used. In other words, the price pressure associated with the actual FyF recommendations is unlikely driven by random chance or by fundamentals related to FyF recommendations. ${ }^{19}$

\subsection{Time-Series Regressions}

The placebo test suggests that the price pressure we document is unlikely driven by market conditions that may trigger the FyF recommendations. To reinforce this point, we run time series regressions in calendar time that control for past returns and other fundamental

\footnotetext{
${ }^{18}$ This is similar to Table 3 , but with an unconditional model, because we cannot condition on the state of the recommendation out of sample.

${ }^{19}$ We also do not find effects when conducting placebo tests on the S\&P500 index and 10-year US Treasury bonds with FyF's actual recommendation dates.
} 
variables that can capture risk factors. The sample of daily returns covers the period between January 2010 and February 2014. The results are reported in Table 6. In these time-series regressions, we regress daily equity or bond performance on event day dummies with and without a comprehensive set of controls. The "Day $i$ " variables correspond to indicator variables that correspond to the $i-t h$ day after a recommendation was sent. The indicator variable equals one when recommending to buy equity and negative one when recommending to sell equity. The indicator variable is zero when there are no recommendation changes. The adjusted equity return is defined again as the difference between the local equity index (IPSA) and the MSCI world market return measured in Chilean pesos. The government bond return is based on the Dow Jones LATixx Chile Government Bond Index. The control variables include the cumulative returns in each of the four previous weeks, the sums of the squared returns in the four previous weeks, the lagged PE ratio, the lagged two- and tenyear government bond yields, lagged inflation, the percentage change in the exchange rate during the previous week, and the contemporaneous daily return of the MSCI world market index. The coefficient on each event day indicator variable thus isolates the magnitude of the "abnormal return" on that day.

Table 6 reports a large and significant price pressure in the equity market on the first day after the recommendation regardless of whether control variables are included or not. The price pressure amounts to 105 basis points without control variables (as in Table 5) and to 77 basis points after the inclusion of the various control variables for fundamental factors. We study a relatively short window of only five days in order to avoid overlap between events, in particular regarding the recommendations that were sent close to each other in June of 2012 (see Table 2).

Consistent with Table 5, columns (3) and (4) of Table 6 report negative price pressure for government bonds during the first days after FyF's recommendations. We find results that exhibit lower statistical significance for government bond returns when compared to equity returns. The price pressure is only marginally significant on day 3 without additional 
controls. The weaker bond results are likely due to the fact that bond funds hold substantially larger cash buffers, as discussed in Section 4.1.

There are several reasons why the largest price pressure takes place on day one. As the FyF recommendations trigger an increasing number of fund switches over time, pension funds might start trading already on day one rather than to wait until day four when these switches become effective. In addition, investors anticipating the price pressure resulting from pension funds' trading may choose to "front-run" pension funds' trades. These frontrunning trades effectively shift the cumulative price pressure to earlier days. Smart investors can also profit from liquidity provision by being the counterparties to pension funds' trades. The subsequent price reversals following the initial price pressure can therefore be interpreted as compensation for liquidity provision. Since short-selling is limited in Chile and there are no financial derivatives for hedging market risk, we expect liquidity provision to be more prevalent in the stock market when pension funds have to sell equity following FyF's recommendations.

\subsection{Subsample Analyses}

Various subsample analyses reported in Table 7 provide supporting evidence for the price pressure hypothesis. FyF's popularity, measured by fund flows and Google search volumes, increased over time as we documented in Figure 2. We should therefore expect that the price impact strengthened over time. We test this hypothesis by splitting our recommendations into two subsamples. The first subsample includes the first seven recommendations and the second subsample includes the remaining eight recommendations. Although results in both subsamples go in the same direction, we find significant price pressure only in the second subsample. The first-day effect is more than twice as large during this second subsample. ${ }^{20}$

We also split our sample based on the direction of switches. Recall that fund A is tilted

\footnotetext{
${ }^{20}$ In unreported results we confirm that the differences between coefficients in the subsample analysis are significant. In particular, the day 1 coefficients in Columns (2) and (4) are significantly higher than those reported in Columns (1) and (3) respectively.
} 
towards equity while fund E holds almost only fixed income securities, hence a switch from A to $\mathrm{E}$ (E to A) implies selling (buying) equity. We find that the effects are concentrated on day one for recommendations to buy equity securities. These results are consistent with the notion that it is easier to front run pension funds' purchases than sales due to the limits of short-selling securities in Chile.

So far, our analysis is focused on the first 15 recommendations which are homogenous in that they represent only switches between funds A and E. Starting with their 16th recommendation on March 6, 2014, FyF began recommending partial fund switches between funds A, C, and E. In our final robustness check we include all 22 recommendations. Since partial fund recommendations are predicted to trigger smaller amounts of trading, we adjust the indicator variables accordingly. The weights, reported in the last column of Table 2, are a function of the magnitude of the recommended switch. For example, a full switch from fund $\mathrm{E}$ to fund $\mathrm{A}$ receives a weight of 1, but a switch from fund $\mathrm{E}$ to an equal-weighted portfolio of funds $\mathrm{A}$ and $\mathrm{E}$ receives a weight of 0.5 , since only half of fund $\mathrm{E}$ needs to be replaced by equity. The last column of Table 7 summarizes the results after including all 22 recommendations. Although the magnitude of the price pressure is reduced after we include partial recommendations, the price impact remains statistically significant.

\subsection{Price Pressure and Abnormal Trading in the Cross Section}

Since pension funds' Chilean equity holdings are dominated by large stocks, we expect more trading and larger price pressure among larger stocks. Figure 6 confirms this hypothesis. Here, large stocks correspond to the ten largest stocks in Santiago's stock exchange and small stocks correspond to the bottom 40 stocks among the 50 largest stocks. As seen in Table 1, the ten largest stocks account for 50\%-60\% of the Chilean stock market capitalization. $^{21}$

\footnotetext{
${ }^{21}$ Other stocks are sparsely traded. For instance, the IPSA index covers only 40 stocks, so we are covering more stocks than the main index in this market. Even some of the stocks in the index are not traded on some days. Stocks outside the largest 50 can be regarded as microcaps. We treat returns as missing when a stock is not traded on the current or the previous day. When pension funds encountered unexpected large
} 
Coordinated noise trading suggests that large stocks are traded more as the pension fund managers implement the switches between funds A and E. The left panels in Figure 6 confirm this conjecture. They plot the cumulative daily abnormal turnover in the equity market during the first 15 days after the FyF recommendations. Daily abnormal turnover is defined as the daily turnover minus the average daily turnover for each stock between days $t-16$ and $t-6$ relative to the day each recommendation is made. Daily abnormal turnover is then cumulated from event day one, and it is value-weighted across stocks in each group. The left panel shows that only large stocks experience heavier than usual trading for the first 11 days after the recommendation. ${ }^{22}$

It is interesting that the turnover of equity securities accumulates gradually over the first two weeks after recommendations, whereas the price impact of equity securities is concentrated on the first day after the recommendation. The delayed response of trading volumes could be due to the fact that pension funds spread out their trades to reduce trading costs and due to the fact that the execution of large flows are delayed for several days since funds cannot switch more than $5 \%$ of their assets in a single day, as explained in more detail in Section 2.

Table 8 studies cross-sectional differences in flow-induced price pressure following Greenwood and Thesmar (2011) and Lou (2012). The intuition is that the price impact of the recommendations is more pronounced for stocks that are over-weighted by the pension fund managers. Thus, the stocks that are held disproportionately by fund A are more exposed to noise trading as pension fund managers scale up (down) their Chilean equity portfolios in order to implement the switches to (from) fund A.

We measure Flow Induced Pressure (FIP) as the value of the signed flow to fund A in month $t$ times the weight of stock $i$ held in fund A's portfolio in month $t-1$ divided by switching requests, it is very unlikely that they will trade any stocks that are not among the 50 largest ones.

${ }^{22}$ Notice that since turnover is a flow, cumulative turnover does not have to converge back to zero. For instance, imagine that turnover follows some arrival rate that for some periods is abnormally high due to unusual rebalancing. After the abnormal volume fades, regular turnover will keep arriving and cumulative turnover will stabilize, but at a permanently higher level. 
the market capitalization of stock $i$ in month $t-1$. A stock with a more positive FIP is predicted to be traded more and appreciate more in value. On the other hand, a stock with a more negative FIP due to outflows is expected to decline in value. We run regressions of cumulative returns over a given holding period, pooling all stocks across all events. ${ }^{23}$ The specification using the cumulative returns on event day $j$ is as follows:

$$
R_{i t}^{c u m_{j}}=\lambda F I P_{i t}+\gamma Z_{i t}+\delta_{t}+\varepsilon_{i t}
$$

We are using only those dates that correspond to event dates. The regression includes time-fixed effects because we pool across different dates for a particular event day. Panel A of Table 8 confirms that stocks with higher FIPs indeed suffer from larger price pressure following the FyF recommendations. The coefficients on FIP are always positive and are significant for days 2 and 3, even after controlling for stock characteristics such as size, bookto-market, and momentum. Panel B confirms the relation between FIP and turnover. Stocks with higher absolute FIPs are traded more after the FyF recommendations. The coefficients on FIP are always positive and are significant during the first four or five days after the recommendations.

The results so far paint a consistent picture: FyF's switching recommendations result in coordinated noise trading. This noise trading shows up in various measures of abnormal trading and coincides with large and significant price pressure in the direction consistent with the FyF recommendation. Finally, the cross-sectional evidence suggests stronger effects among stocks widely held by pension plans since these stocks are predicted to be traded more extensively by pension managers in order to implement the fund switches.

\footnotetext{
${ }^{23}$ In contrast to Table 5, we do not adjust the sign of the cumulative returns depending on whether the recommendation is to buy or sell securities. The direction of the recommendations in Table 8 is captured by the sign of the FIP variable.
} 


\subsection{Excess Volatility}

A long strand of literature starting with Shiller (1981) and Black (1986) suggests that noise trading can affect both the level and the volatility of asset prices. In this subsection, we take advantage of the cross-sectional variation in the stock market to study the impact of noise trading triggered by FyF recommendations on stock return volatility.

In Table 9, we regress the monthly return volatility (computed from daily returns) on the FIP measure and on other controls including lagged volatility. The results confirm a strong link between flow induced pressure and return volatility. A $1 \%$ increase in the flow induced pressure leads to an increase in monthly stock volatility between $0.6 \%$ and $1.8 \%$, depending on whether we control for other stock characteristics, past volatility, and stock fixed effects.

\section{Response from Pension Funds}

Given our findings that fund switches can generate large price pressure and result in excess volatility, it is natural to see how pension funds manage liquidity in response. The changes in their portfolio holdings over time reveal some interesting insights.

Specifically, we plot in Figure 7 the portfolio weights of cash, ETFs, and Chilean equity for fund A (left panel) and the portfolio weights of cash and Chilean fixed income securities for fund E (right panel). The portfolio weights are computed using holdings reported at the end of each month and we aggregate these holdings across AFPs. The sample period starts in July 2011, coinciding with the first FyF recommendation and ends in December 2013.

Pension funds are increasing their holdings of more liquid assets over time. As the fund switches become popular in mid-2012, both funds A and E started to hold more cash. In addition, fund A started to replace the less liquid Chilean stocks with more liquid ETFs. Fund E also decreased its holding of Chilean bonds.

In Table 4, we find that fund flows to a particular pension fund administrator called Modelo are more sensitive to FyF's recommendations. Consequently, we expect Modelo's 
portfolio cash holdings to be higher and to respond more to the recommendations. Table 10 examines the cash holdings of different AFPs in detail. Specifically, we regress monthly cash holdings (in percentage of total fund asset value) of different AFPs on indicator variables for FyF recommendations. The recommendation indicator variable is set equal to one during a month when the recommendation is a switch towards A, negative one when the recommendation is a switch towards $\mathrm{E}$, and zero otherwise.

When we focus on fund A, we find that while all AFPs increase their cash holdings over time, the increase is about twice as large for Modelo (see the coefficient on Trend in Table 10). In addition, the positive coefficient on the recommendation variable suggests that fund A experiences an increase (decrease) in cash holdings following a switch to fund A (E). The response of Modelo's cash holdings to FyF recommendations is also about twice as large compared to the average AFP. We find similar patterns when we focus on fund E. There is a positive trend in cash holdings for all pension funds. There is no similar trend for Modelo, although Modelo's fund E always holds significantly more cash, as evident by the larger constant coefficient (14.4\%). Fund E experiences an increase (decrease) in cash holdings following a switch to fund E (A) and this effect is slightly stronger for Modelo although less significant.

When we examine the cash holdings in funds B, C, and D, we find a significant decrease over time, suggesting that AFPs are moving cash out of these three funds over time. Thus, the increase in the cash holdings of funds $\mathrm{A}$ and $\mathrm{E}$ is not driven by aggregate time trends in cash holdings, since it is not observed for funds B, C, and D.

Figure 7 and Table 10 provide evidence that AFPs respond to the volatile fund flow triggered by FyF recommendations by holding more cash. While more liquid cash holdings help to buffer liquidity shocks, excessive cash holdings can be a performance drag and can hurt the long-term returns of retirement investors. Long-term retirement savers are often suggested to invest in less liquid securities that might provide a liquidity premium.

To estimate the welfare costs of these excess cash holdings we following a welfare cost 
calculation by Calvet, Campbell, and Sodini (2007). We consider a textbook asset allocation problem where a mean-variance investor allocates her investments between a risky portfolio and a risk free asset (cash). Her utility will be maximized at the optimal risky portfolio weight. Any deviation from that optimal weight will result in an utility loss equal to $0.5 A \sigma^{2} D e v^{2}$, where $A, \sigma$, and Dev denote the risk-aversion parameter, the standard deviation on the risky portfolio, and the deviation from the optimal weight accordingly. ${ }^{24}$

Assume funds hold an optimal level of cash before the introduction of FyF in 2011, then increases in cash holdings for funds $\mathrm{A}$ and $\mathrm{E}$ and decreases in cash holdings for funds B, C, and $\mathrm{D}$ both lead to utility losses. Assuming a risk aversion parameter of $A=5$ and a risky portfolio monthly standard deviation of $\sigma=0.2$, we find that a $10 \%$ change in cash holding reduces utility by $0.5 \times 5 \times 0.2^{2} \times 0.10^{2}=0.10 \%$, equivalent to a 10 bps reduction in monthly risk-adjusted returns.

This computed utility loss from holding a sub-optimal portfolio represents only an indirect cost to pension investors. Increased turnover and the associated trading costs are examples of more direct costs to pension investors, especially those investing in funds A and E.

\section{Conclusion}

Taking advantage of several features of the Chilean Pension system, we document a novel channel through which noise trading, if coordinated, can exert large price impact at the aggregate level even when these markets are dominated by institutional investors.

In Chile, where pension assets account for $30 \%$ of free float in the stock market, pension investors often switch their entire pension investments from fund A (holding mostly risky stocks) to fund $\mathrm{E}$ (holding mostly government bonds), or vice versa, in an attempt to "time the market." After a financial advisory firm called "Felices y Forrados" (FyF) gained

\footnotetext{
${ }^{24}$ Let $E R$ and $R f$ denote the expected return on the risky portfolio and the risk free rate, then the optimal weight on the risky portfolio is $w^{*}=(E R-R f) /\left(A \sigma^{2}\right)$. The utility as a function of the weight on the risky portfolio is $U(w)=R f+w(E R-R f)-0.5 A w^{2} \sigma^{2}$. The welfare loss can then calculated as $L=U\left(w^{*}\right)-U\left(w^{\prime}\right)$. After some algebra, it can be shown that $L=0.5 A \sigma^{2}\left(w^{*}-w\right)^{2}$.
} 
popularity in 2011 by providing fund switching recommendations, these signals served as a coordination device among individual noise traders. In order to implement the resulting fund switches, pension fund companies often had to trade $10 \%$ of their domestic equity and $20 \%$ of their bond portfolios within a few days. Not surprisingly, this coordinated noise trading lead to a significant price pressure of around $1 \%$ in the Chilean equity market.

As a response to these frequent fund flows, pension funds in Chile have significantly reduced their holdings of less liquid securities and replaced them with cash. An increase in the proportion of highly liquid securities might not be optimal for retirement investors who typically have long-term investment horizons. One implication of our findings is that too much freedom in reallocating retirement portfolios may destabilize financial markets and impose social costs on retirement investors. 


\section{References}

Agnew, Julie, Pierluigi Balduzzi, and Annika Sunden, 2003, Portfolio choice and trading in a large 401(k) plan, American Economic Review 93, 193-215.

Baker, Malcolm, and Jeffrey Wurgler, 2006, Investor sentiment and the cross-section of stock returns, Journal of Finance 61, 1645-1680.

Barber, Brad M., and Odean Terrance, 2008, All that glitters: The effect of attention and news on the buying behavior of individual and institutional investors, Review of Financial Studies 21, 785-818.

Benartzi, Shlomo, and Richard Thaler, 2001, Naïve diversification strategies in defined contribution savings plans, American Economic Review 91, 79-98.

Bergstresser, Daniel, John Chalmers, and Peter Tufano, 2009, Assessing the costs and benefits of brokers in the mutual fund industry, Review of Financial Studies 22, 41294156.

Bhattacharya, Utpal, Andreas Hackethal, Simon Kaesler, Benjamin Loos, and Steffen Meyer, 2012, Is unbiased financial advice to retail investors sufficient? Answers from a large field study, Review of Financial Studies 25, 975-1032.

Black, Fischer, 1986, Noise, Journal of Finance 41, 529-543.

Brown, Jeffrey R., Nellie Liang, and Scott Weisbenner, 2007, Individual account investment options and portfolio choice: Behavioral lessons from 401(k) plans, Journal of Public Economics 91, 1992-2013.

Calvet, Laurent E., John Y. Campbell, and Paolo Sodini, 2007, Down or out: Assessing the welfare costs of household investment mistakes, Journal of Political Economy 115, 707-747.

Chalmers, John and Jonathan Reuter, 2015, Is conflicted investment advice better than no advice? Working Paper.

Chen, Qi, Itay Goldstein, and Wei Jiang, 2010, Payoff complementarities and financial fragility: Evidence from mutual fund outflows, Journal of Financial Economics 97, 239-262.

Choi, James J., David Laibson, Brigitte C. Madrian, and Andrew Metrick, 2002, Defined contribution pensions: Plan rules, participant decisions, and the path of least resistance, Tax Policy and the Economy 16, 67-113.

Choi, James J., David Laibson, Brigitte Madrian, and Andrew Metrick, 2006, Saving for retirement on the path of least resistance, in: E. McCaffrey and J. Slemrod, eds. Behavioral Public Finance (Russell Sage Foundation). 
Christoffersen, Susan, Richard Evans, and David Musto, 2013, What do consumers' fund flows maximize? Evidence from their brokers' incentives, Journal of Finance 68, 201235.

Christoffersen, Susan, and Mikhail Simutin, 2014, Plan sponsor oversight and benchmarking: Effects on fund risk-taking and activeness, Working paper, University of Toronto.

Cohen, Lauren, and Andrea Frazzini, 2008, Economic links and predictable returns, Journal of Finance 63, 1977-2011.

Cohen, Lauren, and Breno Schmidt, 2009, Attracting flows by attracting big clients, Journal of Finance 64, 2125-2151.

Corwin, Shane A., and Jay F. Coughenour, 2008, Limited attention and the allocation of effort in securities trading, Journal of Finance 63, 3031-3067.

Coval, Joshua, and Erik Stafford, 2007, Asset fire sales (and purchases) in equity markets, Journal of Financial Economics 86, 479-512.

Da, Zhi, Joseph Engelberg, and Pengjie Gao, 2011, In search of attention, Journal of Finance 66, 1461-1499.

Da, Zhi, Joseph Engelberg, and Pengjie Gao, 2015, The sum of all FEARS: Investor sentiment and asset prices, Review of Financial Studies 28, 1-32.

De Long, J. Bradford, Andrei Shleifer, Lawrence H. Summers, and Robert J. Waldmann, 1990, Noise trader risk in financial markets, Journal of Political Economy 98, 703-738.

De Long, J. Bradford, Andrei Shleifer, Lawrence H. Summers, and Robert J. Waldmann, 1990, Positive feedback investment strategies and destabilizing rational speculation, Journal of Finance 45, 379-395.

DeVault, Luke, Richard Sias, and Laura Starks, 2014, Who are the sentiment traders? Evidence from the cross-section of stock returns and demand, Working paper, University of Arizona.

Diamond, Peter, and Valdes-Prieto, Salvador, 1994, Social security reforms, in Barry P. Bosworth, Rudiger Dornbusch, and Raul Laban, eds., The Chilean Economy, Washington, DC: Brookings Institution Press, 257-320.

Diamond, Peter A.,1996, Social security reform in Chile: Two views. An economist's perspective, in Peter A. Diamond, David C. Lindeman, and Howard Young, eds., Social security: What role for the future? National Academy of Social Insurance.

Edelen, Roger, 1999, Investor flows and the assessed performance of open-end mutual funds, Journal of Financial Economics 53, 439-466.

Edwards, Sebastian, 1998, The Chilean pension reform: A pioneering program, in Martin Feldstein, ed., Privatizing Social Security, University of Chicago Press, 33-62. 
Elton, Edwin J., Martin J. Gruber, and Christopher R. Blake, 2006, The adequacy of investment choices offered by 401(k) plans, Journal of Public Economics 90, 12991314.

Elton, Edwin J., Martin J. Gruber, and Christopher R. Blake, 2007, Participant reaction and the performance of funds offered by 401(k) plans, Journal of Financial Intermediation 16, 249-271.

Engelberg, Joseph E., and Christopher A. Parsons, 2011, The causal impact of media in financial markets, Journal of Finance 66, 67-97.

Fang, Lily and Joel Peress, 2009, Media coverage and the cross-section of stock returns, Journal of Finance 64, 2023-2052.

Foerster, Stephen, Juhani Linnainmaa, Brian Melzer, Alessandro Previtero, 2015, Retail financial advice: Does one size fit all? Forthcoming: Journal of Finance.

Frazzini, Andrea, and Owen A. Lamont, 2008, Dumb money: Mutual fund flows and the cross-section of stock returns, Journal of Financial Economics 88, 299-322.

Gennaioli, Nicola, Andrei Shleifer, and Robert Vishny, 2015, Money doctors, Journal of Finance 70, 91-114.

Greenwood, Robin, and Andrei Shleifer, 2014, Expectations of returns and expected returns, Review of Financial Studies 27, 714-746.

Greenwood, Robin, and David Thesmar, 2011, Stock price fragility, Journal of Financial Economics 102 (3), 471-490.

Gurun, Umit G., and Alexander W. Butler, 2012, Don't believe the hype: Local media slant, local advertising, and firm value, Journal of Finance 67, 561-598.

Huberman, Gur, and Wei Jiang, 2006, Offering versus choice in 401(k) plans: Equity exposure and number of funds, Journal of Finance 61, 763-801.

Inderst, Roman, and Marco Ottaviani, 2012a, Financial advice, Journal of Economic Literature 50, 494-512.

Inderst, Roman, and Marco Ottaviani, 2012b, How (not) to pay for advice: A framework for consumer financial protection, Journal of Financial Economics 105, 393-411.

Kogan, Leonid, Stephen A. Ross, Jiang Wang, and Mark M. Westerfield, 2006, The price impact and survival of irrational traders, Journal of Finance 61(1), 195 - 229.

Kogan, Leonid, Stephen A. Ross, Jiang Wang, and Mark M. Westerfield, 2009, Market selection, Working Paper, MIT.

Lou, Dong, 2012, A flow-based explanation for return predictability, Review of Financial Studies 25, 3457-3489. 
Loughran, Tim, and Bill McDonald, 2011, When is a liability not a liability? Textual analysis, dictionaries, and 10-Ks, Journal of Finance 66, 35-65.

Lusardi, Annamaria and Olivia S. Mitchell, 2007, Baby boomer retirement security: The roles of planning, financial literacy, and housing wealth, Journal of Monetary Economics 54, 205-224.

Madrian, Brigitte, and Dennis F. Shea, 2001, The power of suggestion: Inertia in 401(k) participation and savings behavior, Quarterly Journal of Economics 116, 1149-1187.

Mitchell, Olivia S. and Flavia Ataliba Barreto, 1997, After Chile, what? Second-round pension reforms in Latin America, Revista de Analisis Economico 12, 3-36.

Mitchell, Olivia S., Petra E. Todd, and David Bravo, 2009, Learning from the Chilean experience: The determinants of pension switching, in Annamaria Lusardi,ed., Overcoming the saving slump: How to increase the effectiveness of financial education and saving programs, Chicago, 301-323.

Mullainathan, Sendhil, Markus Nöth, and Antoinette Schoar, 2012, The market for financial advice: An audit study, Working Paper.

Opazo, Luis, Claudio Raddatz, and Sergio L. Schmukler, 2014, Institutional investors and long-term investment: Evidence from Chile, Policy Research Working Paper Series 6922, The World Bank

Peress, Joel, 2014, The media and the diffusion of information in financial markets: evidence from newspaper strikes, Journal of Finance 69, 2007-2043.

Peress, Joel, and Daniel Schmidt, 2014, Glued to the TV: The trading activity of distracted investor, Working Paper, INSEAD, HEC Paris.

Pool, Veronika, Clemens Sialm, and Irina Stefanescu, 2015, It pays to set the menu: 401(k) investment options in mutual funds, Forthcoming: Journal of Finance.

Raddatz, Claudio, and Sergio Schmukler, 2013, Deconstructing herding: Evidence from pension fund investment behavior, Journal of Financial Services Research 43, 99-126.

Shiller, Robert, 1981, Do stock prices move too much to be justified by subsequent changes in dividends? American Economic Review 71, 421-436.

Shleifer, Andrei, 1986, Do demand curves for stocks slope down? Journal of Finance 41, 579-590.

Shleifer, Andrei and Lawrence H. Summers, 1990, The noise trader approach to finance. Journal of Economic Perspectives 4, 19-33.

Shleifer, Andrei and Robert W. Vishny, 1997, The limits of arbitrage. Journal of Finance $52,35-55$. 
Sialm, Clemens, Laura Starks, and Hanjiang Zhang, 2015, Defined contribution pension plans: Sticky or discerning money? Journal of Finance 70, 805-838.

Sias, Richard W., 2004, Institutional herding, Review of Financial Studies 17, 165-206.

Stambaugh, Robert F., 2014, Investment noise and trends, Journal of Finance 69 (4), 1415-1453.

Stein, Jeremy, 2005, Why are most funds open-end? Competition and the limits of arbitrage, Quarterly Journal of Economics 120, 247-272.

Stein, Jeremy, 2009, Sophisticated investors and market efficiency, Journal of Finance 64, $1517-1548$.

Tetlock, Paul C., 2007, Giving content to investor sentiment: The role of media in the stock market, Journal of Finance 62, 1139-1168.

Von Gaudecker, Hans M., 2015, How does household portfolio diversification vary with financial literacy and financial advice? Journal of Finance 70, 489-507.

Wurgler, Jeffrey, and Ekaterina Zhuravskaya, 2002, Does arbitrage flatten demand curves for stocks? Journal of Business 75, 583-608. 


\section{Number of voluntary daily fund switches since January 2011}

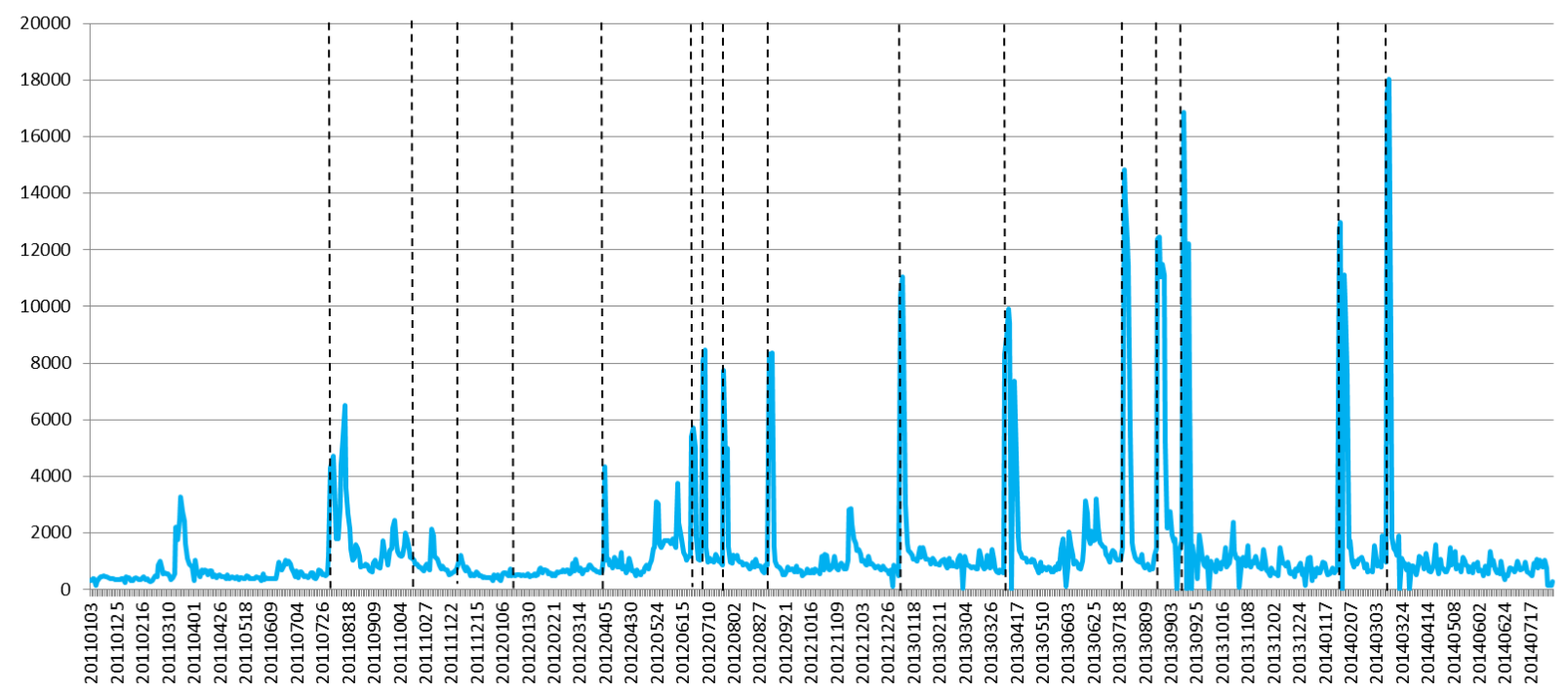

Source: Superintendencia de Pensiones, Chile.

Figure 1: Daily number of individuals requesting fund switches. Vertical lines mark the dates when FyF sent a switch recommendation. The figure was provided to us by the Superintendencia de Pensiones, and it is based on data from administrative records that are not publicly available; vertical lines with dates were added by the authors. 
(a) Panel A.

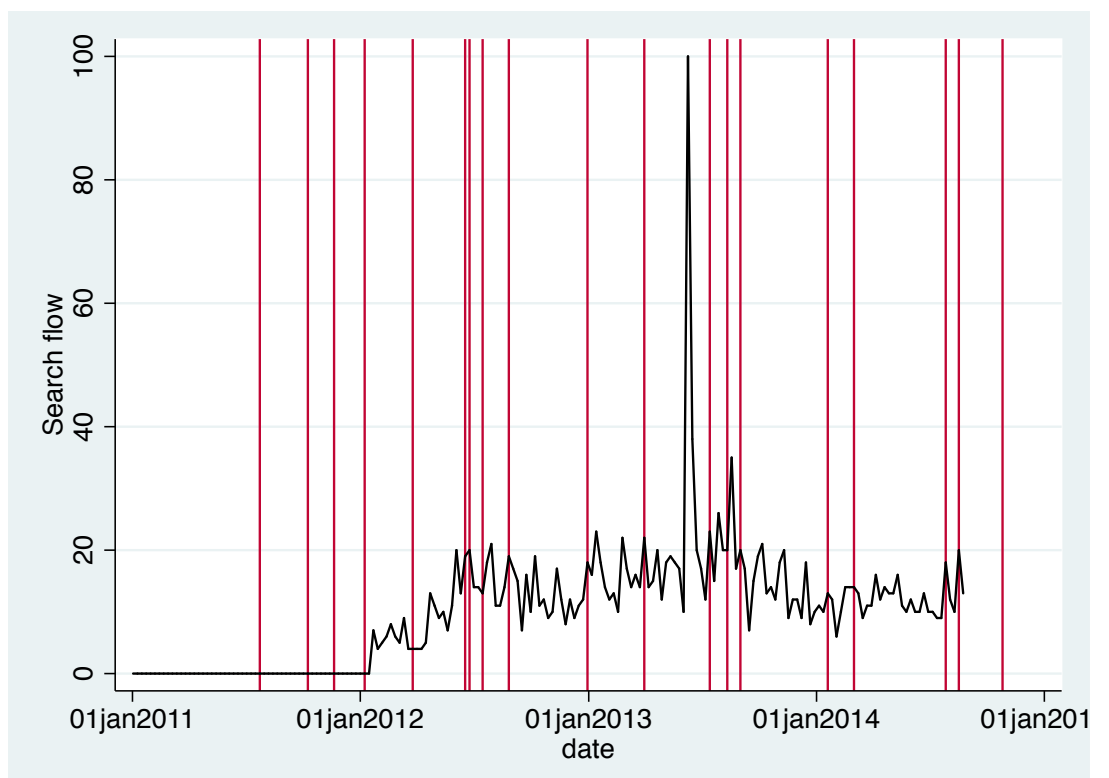

(b) Panel B.

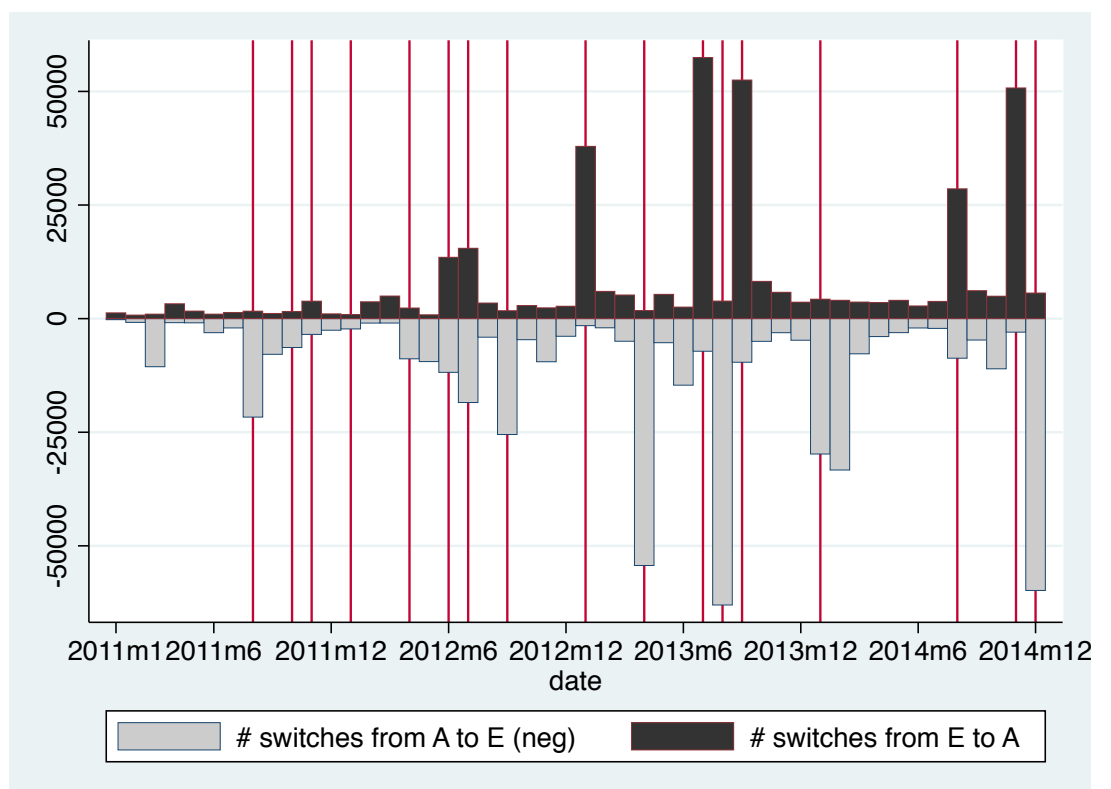

Figure 2: Panel A shows the weekly Google Search Volume Index (SVI) on "Felices y Forrados" since 2011. Panel B shows the monthly number of fund switches requested by pension fund investors from fund $\mathrm{E}$ to $\mathrm{A}$, and from fund $\mathrm{A}$ to $\mathrm{E}$ (shown as a negative number). Vertical lines mark the switching recommendations by Felices y Forrados, adjusted in Panel $\mathrm{B}$ so that a recommendation in the last three days of a month is marked in the following month. 

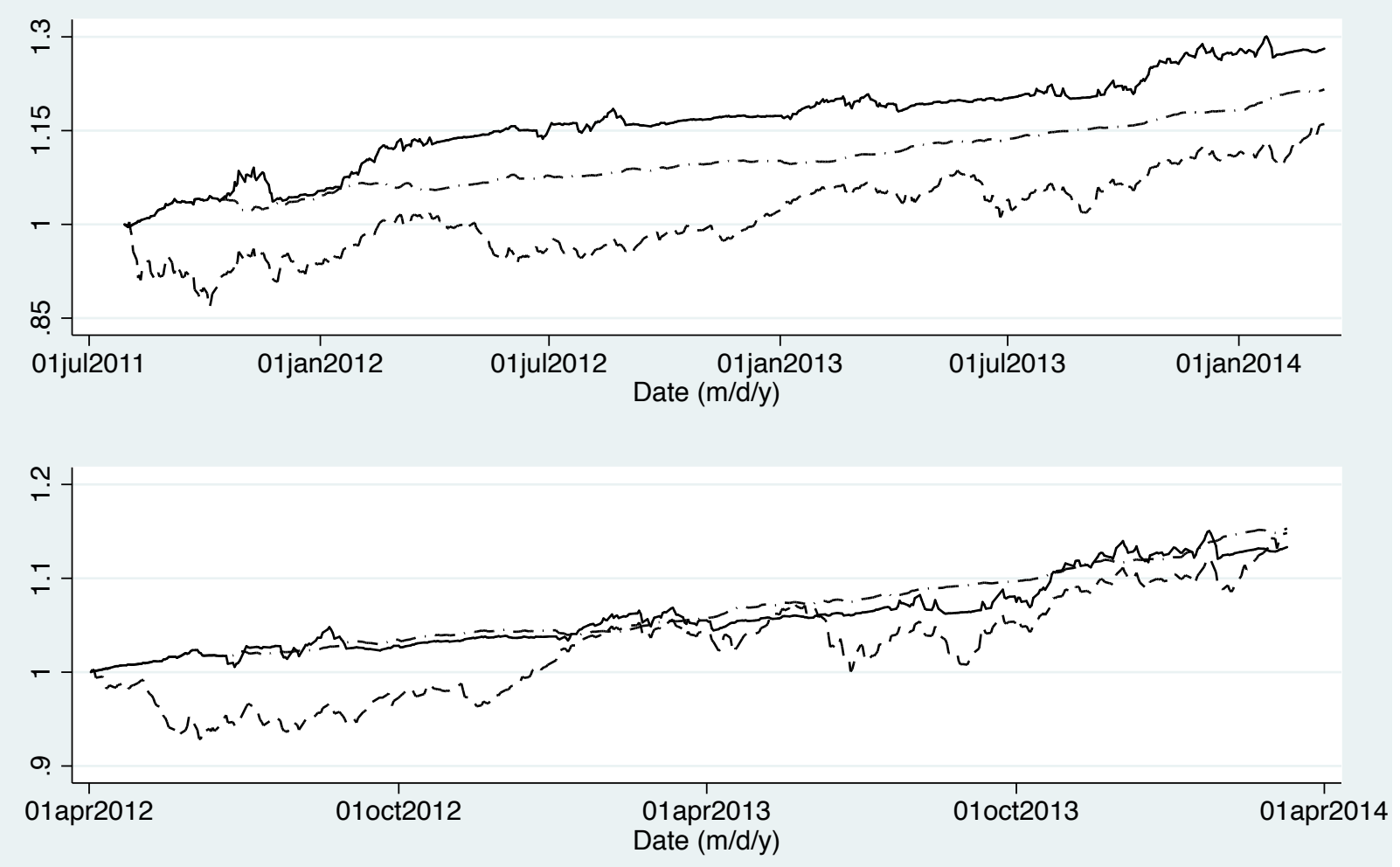

$$
----- \text { Fund } A \text {-.-.-. Fund E } \longrightarrow \text { FyF }
$$

Figure 3: Cumulative returns to investment strategies. We compute the cumulative returns to following three investment strategies: (1) Buy-and-hold fund A (Fund A); (2) Buy-andhold fund $\mathrm{E}$ (Fund E); (3) Switching between fund A and E following FyF's recommendations immediately after receiving the recommendation $(\mathrm{FyF})$. We consider two cases: we invest a dollar in each strategy starting from (1) the first FyF recommendation (Jul 27, 2011); (2) the fifth recommendation (Mar 29, 2012). 


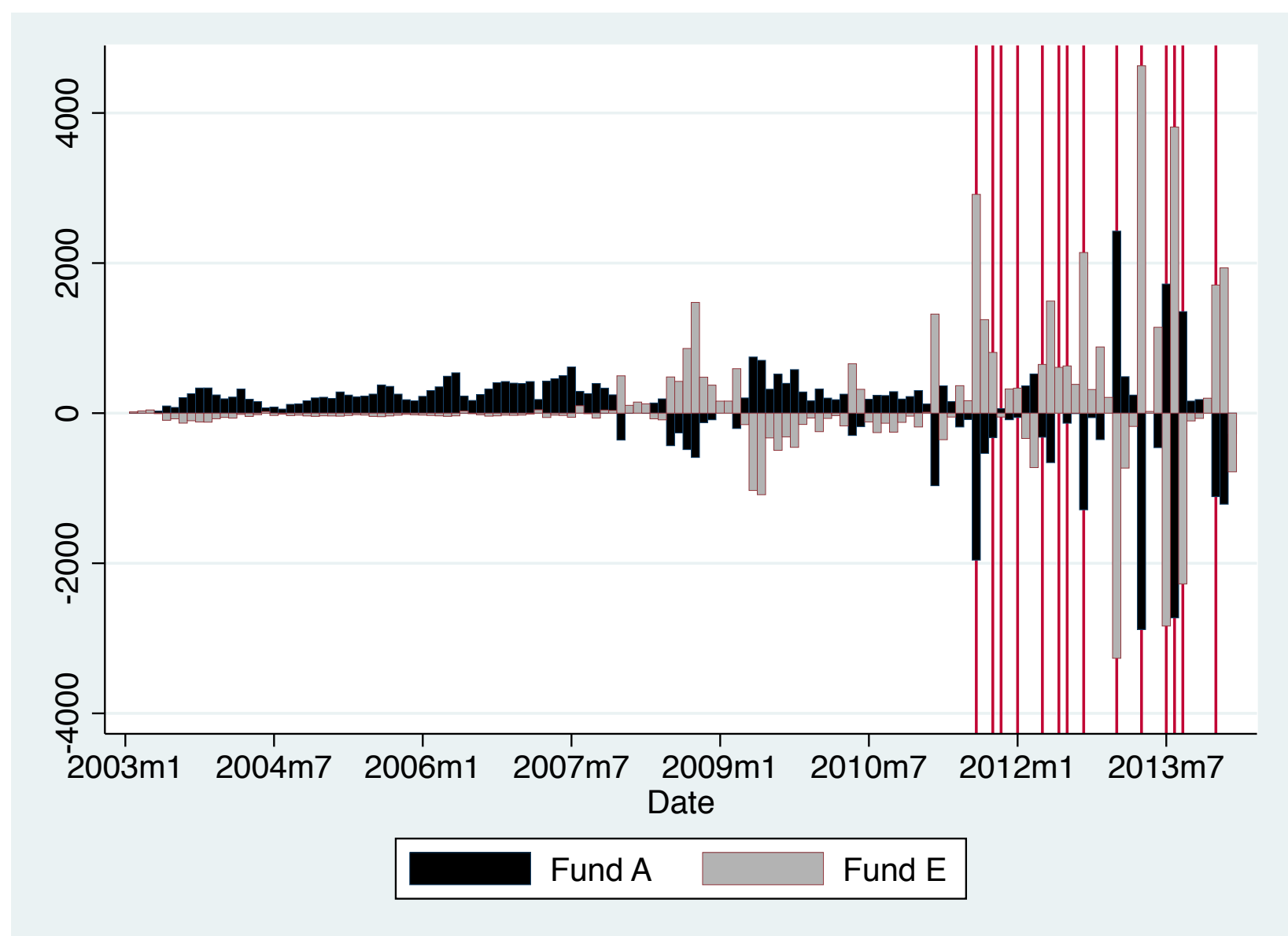

Figure 4: This figure shows the monthly dollar flows of funds A and E. We plot the aggregate dollar flows (in millions of USD) of the equity fund (A) and the fixed income fund (E). Positive and negative numbers indicate inflows and outflows, respectively. Vertical lines show the months when there was a switch recommendation by Felices y Forrados, adjusted so that a recommendation in the last three days of a month is marked in the following month. 


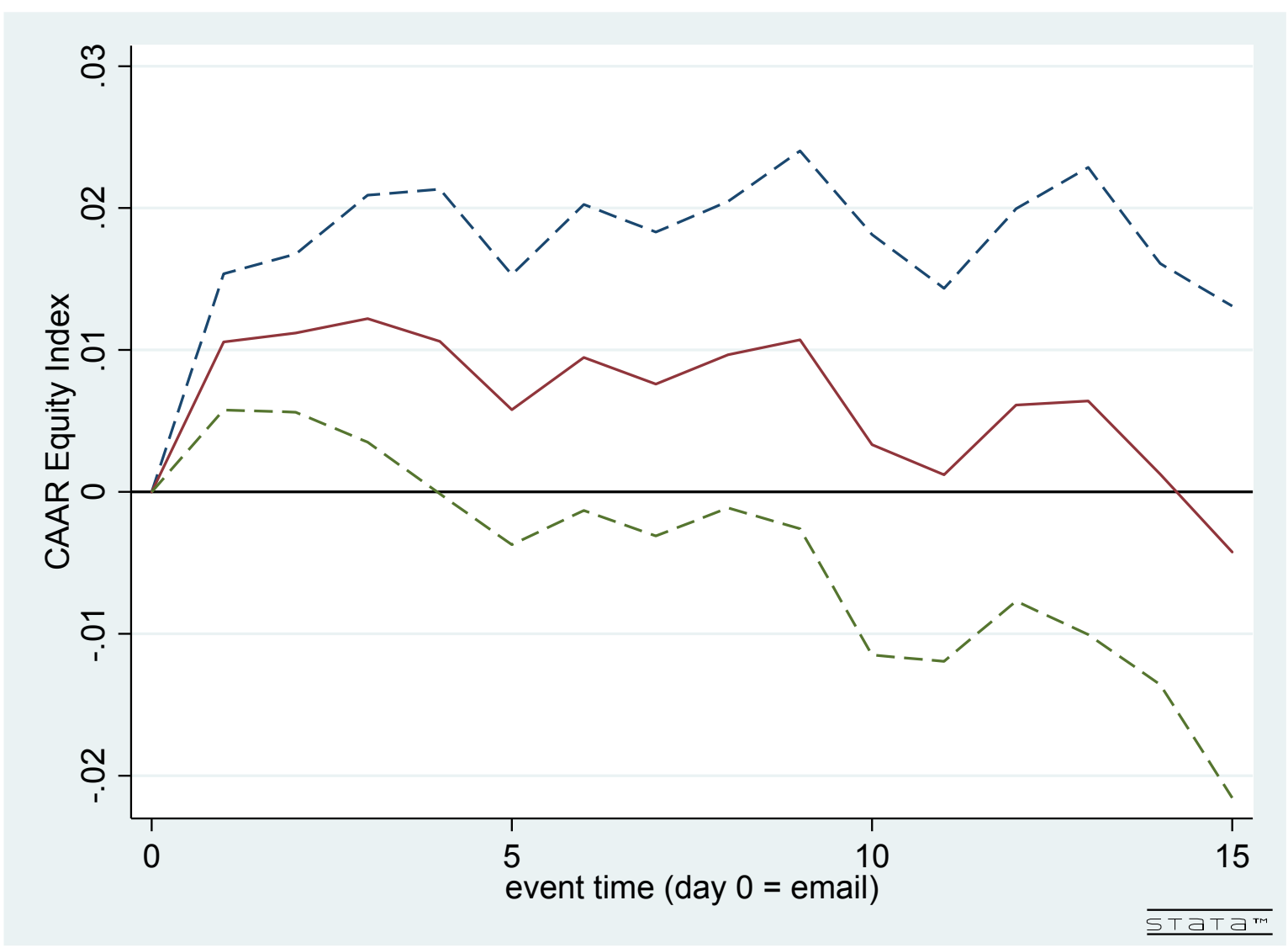

Figure 5: Cumulative average adjusted returns for FyF's first 15 recommendations. The figure shows results for returns on Santiago's stock exchange equity index adjusted by subtracting returns (in pesos) of the MSCI World index. Day 0 is defined as the day when the recommendation is sent, which occurs after the market has closed. Event days correspond to trading days after recommendations. The solid line shows the average of the cumulative adjusted returns across the first 15 recommendations of FyF in Table 2 on a given event day. Dashed lines correspond to $90 \%$ confidence intervals. 

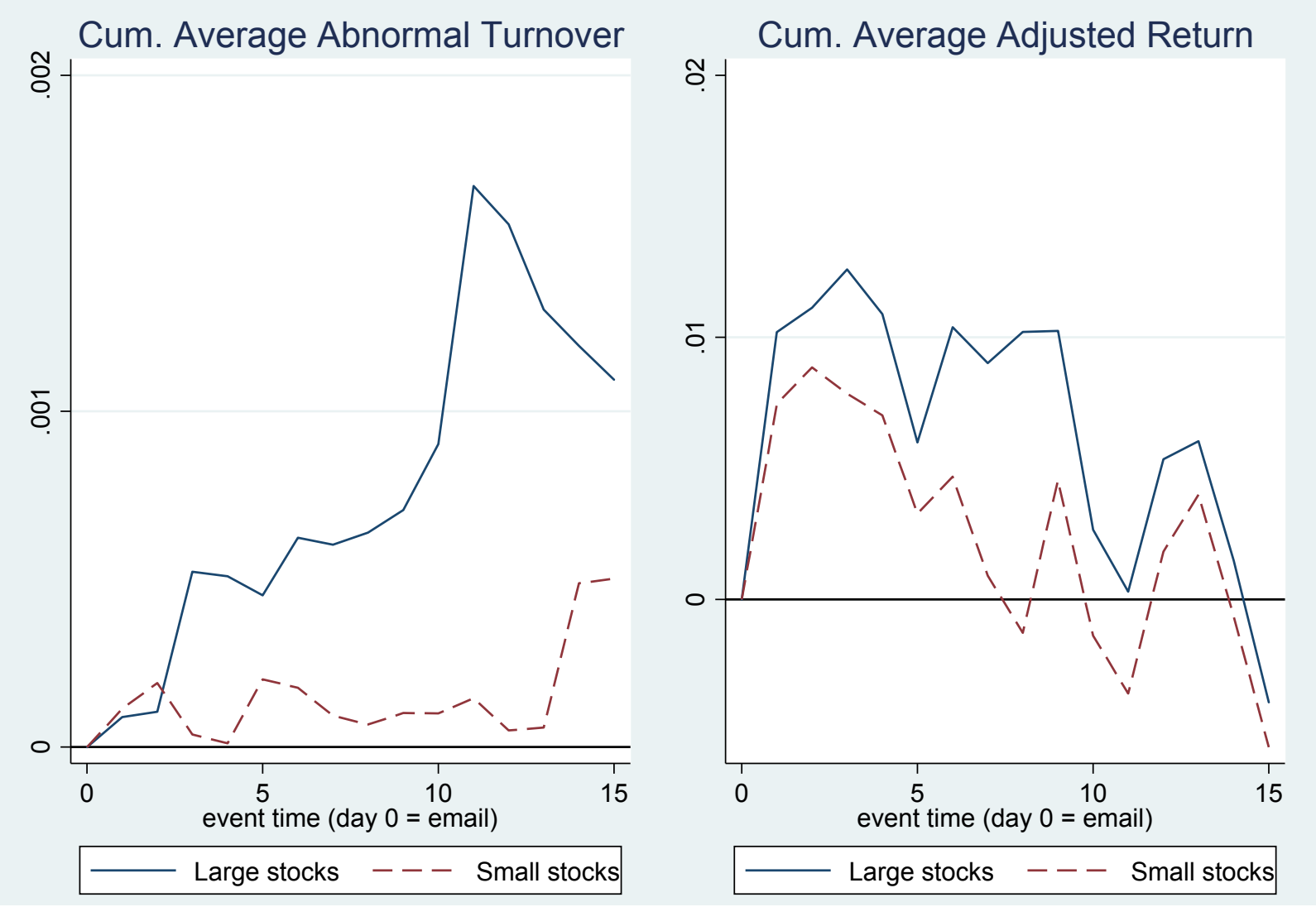

Figure 6: Cumulative average abnormal turnover (left), and cumulative average adjusted returns (right), for the FyF's first 15 recommendations for stocks separated by size. Day 0 is defined as the day when the recommendation is sent, which occurs after the market has closed. Large stocks correspond to the ten largest stocks in Santiago's stock exchange, small stocks are the bottom forty stocks among the 50 largest stocks. Abnormal turnover is defined as turnover minus the average daily turnover for each stock between days $t-16$ and $t-6$ from the day each recommendation is made. Stock returns are adjusted by subtracting returns (in pesos) of the MSCI World index. 

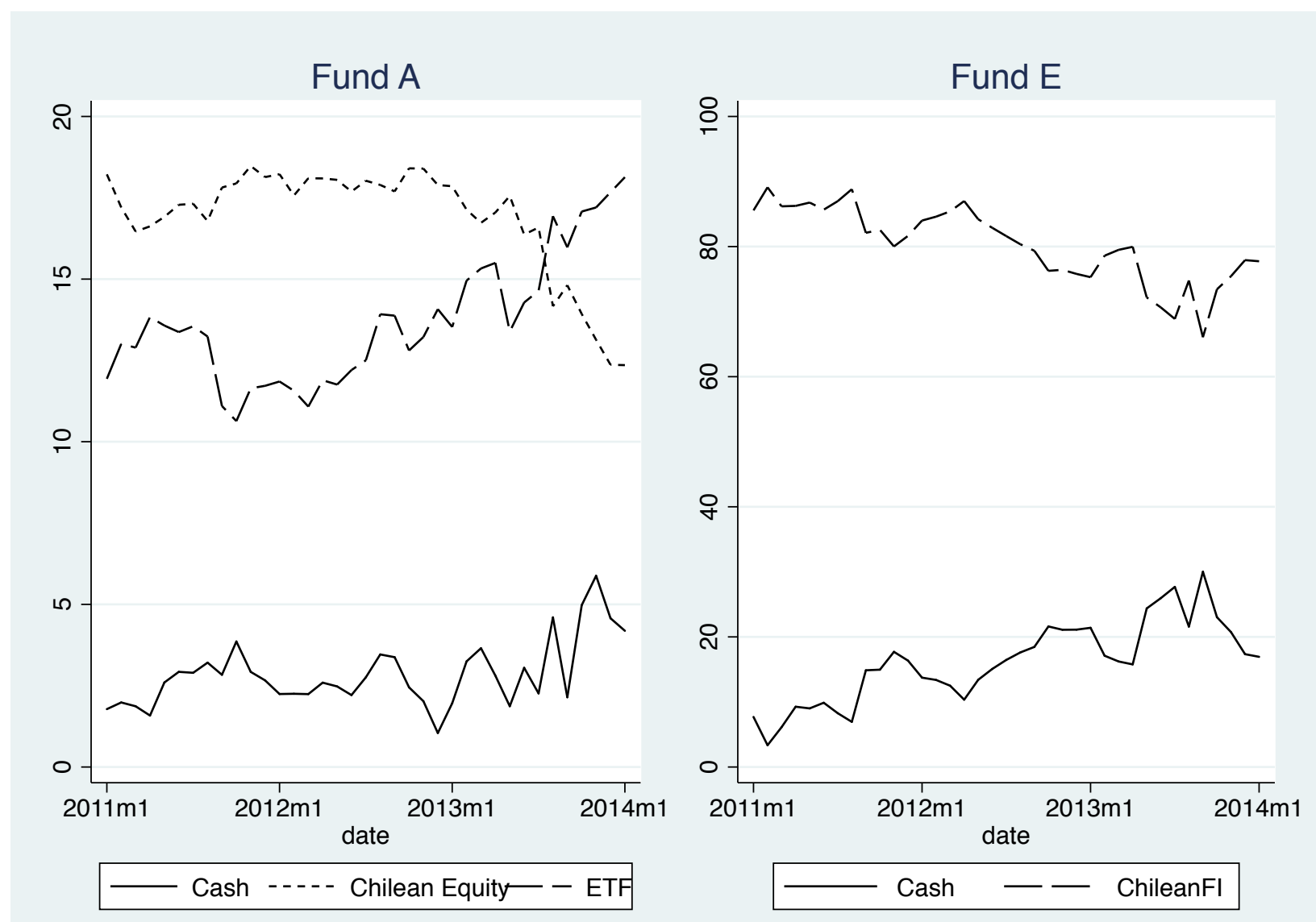

Figure 7: Portfolio holdings of fund A and E over time. We plot the portfolio weights of cash, ETFs, and Chilean equity for fund A (left); the portfolio weights of cash and Chilean fixed income securities for fund E (right). The portfolio weights are computed using holdings reported at the end of each month and we aggregate these holdings across AFPs. The sample period starts in July 2011, coinciding with the first FyF recommendation and it ends in December 2013. 
Table 1: Characteristics of five fund classes. Panel A reports the total asset values, portfolio compositions, and investor demographics of funds A to E. The indicator variables "young," "middle," and "old" correspond to investors under 30, between 30 and 55, and above 55, respectively. These characteristics are first aggregated across different AFPs each month, then averaged across time starting from 2011. Panel B reports the descriptive statistics of the portfolio composition of pension funds $\mathrm{A}$ and $\mathrm{E}$ and that of the market portfolio. Data corresponds to the pension system aggregates during the first six months of 2011. Data is taken from administrative records published by the Superintendencia de Pensiones.

Panel A

\begin{tabular}{lrrrrr}
\hline Fund & Fund A & Fund B & Fund C & Fund D & Fund E \\
\hline Assets (billion USD) & 28.0 & 27.9 & 60.6 & 22.4 & 14.1 \\
Portfolio weights (\%) & & & & & \\
Cash & 2.9 & 4.9 & 4.9 & 9.6 & 16.4 \\
Chilean fixed income & 9.0 & 25.1 & 43.4 & 60.4 & 80.1 \\
Chilean equity & 16.9 & 17.4 & 13.8 & 6.6 & 1.1 \\
International MF & 52.0 & 39.6 & 26.6 & 16.5 & 0.4 \\
ETF & 13.7 & 7.8 & 5.6 & 3.7 & 0.9 \\
CEF & 4.5 & 4.1 & 4.1 & 2.0 & 0.0 \\
Others & 1.1 & 1.1 & 1.5 & 1.1 & 1.1 \\
Demographics (\%) & & & & & \\
Young & 45.0 & 46.9 & 6.8 & 5.3 & 17.0 \\
Middle & 53.7 & 50.0 & 82.8 & 31.0 & 59.7 \\
Old & 1.3 & 3.2 & 10.4 & 63.6 & 23.3 \\
Men & 58.8 & 53.1 & 52.6 & 43.1 & 57.7 \\
\hline
\end{tabular}

Panel B

\begin{tabular}{lrrr}
\hline & Fund A & Fund E & Market \\
\hline Average \% of Domestic Equity in largest 10 stocks & 49.8 & 55.0 & 58.5 \\
Average \% of Domestic Equity in 2nd largest 10 stocks & 26.4 & 24.4 & 20.7 \\
Average \% of Domestic Equity in 3rd largest 10 stocks & 9.2 & 14.6 & 8.0 \\
Average \% of Domestic Equity in 4th largest 10 stocks & 4.4 & 1.5 & 5.3 \\
Average \% of Domestic Equity in 5th largest 10 stocks & 1.5 & 1.1 & 3.5 \\
Average \% of Domestic Equity in other stocks & 8.6 & 3.9 & 4.1 \\
Average \% of Domestic Fixed Income in Government Bonds & 39.0 & 38.2 & 37.7 \\
Average Maturity Government Bonds (years) & 10.0 & 11.0 & 8.7 \\
\hline
\end{tabular}


Table 2: List of recommendations sent by FyF. Recommendations are sent to subscribers after the market closes on the evening of the day in column "Date sent". The first 15 recommendations consider only funds A and E. The column labeled as "Weight" is taken from the point of view of the pressure caused in the equity market: 1 represents recommendations going towards equity and -1 represents recommendations going towards bonds. Partial weights follow a similar logic.

\begin{tabular}{|c|c|c|c|c|c|}
\hline \multicolumn{2}{|c|}{ Recommendation } & \multicolumn{2}{|c|}{ Recommended change } & \multirow{2}{*}{ Buying pressure on } & \multirow{2}{*}{ Weight } \\
\hline Number & Date sent & From fund & To fund & & \\
\hline 1 & July 27,2011 & $\mathrm{~A}$ & $\mathrm{E}$ & Bonds & -1 \\
\hline 2 & October 12, 2011 & $\mathrm{E}$ & $\mathrm{A}$ & Equity & 1 \\
\hline 3 & November 22, 2011 & $\mathrm{~A}$ & $\mathrm{E}$ & Bonds & -1 \\
\hline 4 & January 11, 2012 & $\mathrm{E}$ & $\mathrm{A}$ & Equity & 1 \\
\hline 5 & March 29, 2012 & $\mathrm{~A}$ & $\mathrm{E}$ & Bonds & -1 \\
\hline 6 & June 19, 2012 & $\mathrm{E}$ & $\mathrm{A}$ & Equity & 1 \\
\hline 7 & June 28, 2012 & $\mathrm{~A}$ & $\mathrm{E}$ & Bonds & -1 \\
\hline 8 & July 19, 2012 & $\mathrm{E}$ & $\mathrm{A}$ & Equity & 1 \\
\hline 9 & August 29, 2012 & $\mathrm{~A}$ & $\mathrm{E}$ & Bonds & -1 \\
\hline 10 & January 2, 2013 & $\mathrm{E}$ & $\mathrm{A}$ & Equity & 1 \\
\hline 11 & April 2, 2013 & $\mathrm{~A}$ & $\mathrm{E}$ & Bonds & -1 \\
\hline 12 & July 17,2013 & $\mathrm{E}$ & $\mathrm{A}$ & Equity & 1 \\
\hline 13 & August 16, 2013 & $\mathrm{~A}$ & $\mathrm{E}$ & Bonds & -1 \\
\hline 14 & September 6, 2013 & $\mathrm{E}$ & $\mathrm{A}$ & Equity & 1 \\
\hline 15 & January 24, 2014 & $\mathrm{~A}$ & $\mathrm{E}$ & Bonds & -1 \\
\hline 16 & March 6, 2014 & $\mathrm{E}$ & $0.5 \mathrm{C}+0.5 \mathrm{E}$ & Stocks & 0.25 \\
\hline 17 & August 5, 2014 & $0.5 \mathrm{C}+0.5 \mathrm{E}$ & $\mathrm{E}$ & Bonds & -0.25 \\
\hline 18 & August 19, 2014 & $\mathrm{E}$ & $0.5 \mathrm{~A}+0.5 \mathrm{E}$ & Stocks & 0.5 \\
\hline 19 & October 30, 2014 & $0.5 \mathrm{~A}+0.5 \mathrm{E}$ & $\mathrm{A}$ & Stocks & 0.5 \\
\hline 20 & December 15, 2014 & $\mathrm{~A}$ & $\mathrm{E}$ & Bonds & -1 \\
\hline 21 & February 12, 2015 & $\mathrm{E}$ & $0.5 \mathrm{~A}+0.5 \mathrm{E}$ & Stocks & 0.5 \\
\hline 22 & March 18, 2015 & $0.5 \mathrm{~A}+0.5 \mathrm{E}$ & $\mathrm{A}$ & Stocks & 0.5 \\
\hline
\end{tabular}


Table 3: Determinants of FyF recommendations. We estimate two separate logit models. The first model, presented in columns (1) to (3), corresponds to a logit model where the dependent variable takes the value of one if a recommendation to switch to fund $\mathrm{A}$ is issued that day, conditional on fund E being the currently recommended fund. The second model, summarized in columns (4) to (6), corresponds to a logit model where the dependent variable takes the value of one if a recommendation to switch to fund $\mathrm{E}$ is issued that day, conditional on fund A being the currently recommended fund. The explanatory variables in the logit model are lagged returns of stocks and government bonds, and fundamentals such as the exchange rates changes, and the rate of inflation. The models are estimated with a penalized maximum likelihood estimator because of the low prevalence of the outcome. We use daily data between recommendation 1 and 16. Robust standard errors are reported in parentheses. *** $p<0.01, * * p<0.05, * p<0.1$.

\begin{tabular}{|c|c|c|c|c|c|c|}
\hline & \multicolumn{3}{|c|}{ Fund $\mathrm{E}$ to Fund A } & \multicolumn{3}{|c|}{ Fund $\mathrm{A}$ to Fund $\mathrm{E}$} \\
\hline & $(1)$ & $(2)$ & (3) & (4) & $(5)$ & $(6)$ \\
\hline Chilean equity index return week -1 & $\begin{array}{l}56.67^{* * *} \\
(2.65)\end{array}$ & $\begin{array}{c}104.40^{* *} \\
(2.51)\end{array}$ & $\begin{array}{l}77.56^{*} \\
(1.80)\end{array}$ & $\begin{array}{c}-5.34 \\
(-0.30)\end{array}$ & $\begin{array}{c}-5.19 \\
(-0.28)\end{array}$ & $\begin{array}{c}-2.57 \\
(-0.12)\end{array}$ \\
\hline Chilean equity index return week -2 & $\begin{array}{l}13.24 \\
(0.88)\end{array}$ & $\begin{array}{l}14.58 \\
(0.80)\end{array}$ & $\begin{array}{l}13.15 \\
(0.44)\end{array}$ & $\begin{array}{l}12.25 \\
(0.66)\end{array}$ & $\begin{array}{c}4.35 \\
(0.23)\end{array}$ & $\begin{array}{c}3.77 \\
(0.17)\end{array}$ \\
\hline Chilean equity index return week -3 & $\begin{array}{l}19.59 \\
(1.27)\end{array}$ & $\begin{array}{c}63.06^{*} \\
(1.83)\end{array}$ & $\begin{array}{l}31.65 \\
(0.75)\end{array}$ & $\begin{array}{l}-23.10 \\
(-1.28)\end{array}$ & $\begin{array}{c}-27.02 \\
(-1.38)\end{array}$ & $\begin{array}{l}-16.09 \\
(-0.71)\end{array}$ \\
\hline Chilean equity index return week -4 & $\begin{array}{c}0.78 \\
(0.05)\end{array}$ & $\begin{array}{l}72.24^{*} \\
(1.90)\end{array}$ & $\begin{array}{l}47.09 \\
(1.24)\end{array}$ & $\begin{array}{c}1.25 \\
(0.08)\end{array}$ & $\begin{array}{c}-2.89 \\
(-0.16)\end{array}$ & $\begin{array}{l}-6.82 \\
(-0.29)\end{array}$ \\
\hline Chilean gov index return week -1 & $\begin{array}{l}14.43 \\
(0.13)\end{array}$ & $\begin{array}{l}47.06 \\
(0.29)\end{array}$ & $\begin{array}{l}77.54 \\
(0.41)\end{array}$ & $\begin{array}{r}219.20^{*} \\
(1.66)\end{array}$ & $\begin{array}{r}133.80 \\
(1.44)\end{array}$ & $\begin{array}{c}104.80 \\
(1.05)\end{array}$ \\
\hline Chilean gov index return week -2 & $\begin{array}{l}-60.33 \\
(-0.55)\end{array}$ & $\begin{array}{r}-137.40 \\
(-1.16)\end{array}$ & $\begin{array}{r}-129.70 \\
(-1.08)\end{array}$ & $\begin{array}{c}3.43 \\
(0.04)\end{array}$ & $\begin{array}{l}-11.82 \\
(-0.15)\end{array}$ & $\begin{array}{l}-10.29 \\
(-0.12)\end{array}$ \\
\hline Chilean gov index return week -3 & $\begin{array}{r}141.70 \\
(0.95)\end{array}$ & $\begin{array}{l}46.32 \\
(0.37)\end{array}$ & $\begin{array}{l}55.21 \\
(0.41)\end{array}$ & $\begin{array}{l}-41.00 \\
(-0.43)\end{array}$ & $\begin{array}{l}-23.81 \\
(-0.27)\end{array}$ & $\begin{array}{l}-37.24 \\
(-0.40)\end{array}$ \\
\hline Chilean gov index return week -4 & $\begin{array}{r}-113.00 \\
(-1.11)\end{array}$ & $\begin{array}{r}-159.40^{*} \\
(-1.67)\end{array}$ & $\begin{array}{r}-156.30 \\
(-1.43)\end{array}$ & $\begin{array}{c}-159.30^{* *} \\
(-2.11)\end{array}$ & $\begin{array}{r}-148.80^{*} \\
(-1.92)\end{array}$ & $\begin{array}{r}-143.30 \\
(-1.64)\end{array}$ \\
\hline Exchange rate change week -1 & & $\begin{array}{l}10.82 \\
(0.22)\end{array}$ & $\begin{array}{c}-3.32 \\
(-0.06)\end{array}$ & & $\begin{array}{c}54.22^{* *} \\
(1.99)\end{array}$ & $\begin{array}{l}53.91^{*} \\
(1.90)\end{array}$ \\
\hline Exchange rate change week -2 & & $\begin{array}{l}-39.86 \\
(-0.90)\end{array}$ & $\begin{array}{l}-37.59 \\
(-0.77)\end{array}$ & & $\begin{array}{l}10.82 \\
(0.34)\end{array}$ & $\begin{array}{l}18.33 \\
(0.50)\end{array}$ \\
\hline Exchange rate change week -3 & & $\begin{array}{l}29.39 \\
(0.83)\end{array}$ & $\begin{array}{l}19.30 \\
(0.54)\end{array}$ & & $\begin{array}{c}9.51 \\
(0.31)\end{array}$ & $\begin{array}{l}15.99 \\
(0.45)\end{array}$ \\
\hline Exchange rate change week -4 & & $\begin{array}{c}142.30^{* * *} \\
(2.80)\end{array}$ & $\begin{array}{c}115.10^{* *} \\
(2.46)\end{array}$ & & $\begin{array}{c}-6.23 \\
(-0.27)\end{array}$ & $\begin{array}{l}-3.59 \\
(-0.14)\end{array}$ \\
\hline Inflation & & $\begin{array}{l}-51.92 \\
(-0.42)\end{array}$ & $\begin{array}{c}-0.19 \\
(-0.00)\end{array}$ & & $\begin{array}{l}-54.38 \\
(-0.35)\end{array}$ & $\begin{array}{l}-62.01 \\
(-0.37)\end{array}$ \\
\hline MSCI Latam index return week -1 & & & $\begin{array}{c}9.79 \\
(0.37)\end{array}$ & & & $\begin{array}{l}-1.36 \\
(-0.06)\end{array}$ \\
\hline MSCI Latam index return week -2 & & & $\begin{array}{c}0.48 \\
(0.02)\end{array}$ & & & $\begin{array}{l}-3.12 \\
(-0.15)\end{array}$ \\
\hline MSCI Latam index return week -3 & & & $\begin{array}{l}22.15 \\
(0.75)\end{array}$ & & & $\begin{array}{l}-22.68 \\
(-1.30)\end{array}$ \\
\hline MSCI Latam index return week -4 & & & $\begin{array}{l}15.92 \\
(0.64) \\
\end{array}$ & & & $\begin{array}{c}4.58 \\
(0.27)\end{array}$ \\
\hline $\mathrm{N}$ & 352 & 336 & 336 & 441 & 441 & 441 \\
\hline Pseudo $R^{2}$ & 0.08 & 110.15 & 0.13 & 0.08 & 0.08 & 0.08 \\
\hline
\end{tabular}


Table 4: Demographics and flows across pension companies. Panel A reports the fractions of young investors in funds $\mathrm{A}$ and $\mathrm{E}$ across different pension fund administrators (AFPs) in Chile. In Panel B, we regress monthly fund flows of different AFPs on FyF recommendation indicator variables and interaction terms. Although not reported, the regressions also include lagged fund flows and returns up to 6 lags. The regressions also include AFP fixed effects.

Panel A

\begin{tabular}{lcc}
\hline & $\begin{array}{c}\text { Percentage of Young Investors } \\
\text { (below }\end{array}$ \\
\cline { 2 - 3 } AFP & Fund A & Fund $\mathrm{E}$ \\
\hline MODELO & $94 \%$ & $53 \%$ \\
CAPITAL & $63 \%$ & $24 \%$ \\
CUPRUM & $50 \%$ & $19 \%$ \\
HABITAT & $66 \%$ & $27 \%$ \\
PLANVITAL & $64 \%$ & $40 \%$ \\
PROVIDA & $69 \%$ & $25 \%$ \\
\hline
\end{tabular}

Panel B

\begin{tabular}{lcc}
\hline & \multicolumn{2}{c}{$\begin{array}{c}\text { Dependent Variable: } \\
\text { Fund Flows (\%) }\end{array}$} \\
\cline { 2 - 3 } Variables & Fund A & Fund E \\
\hline Switch towards A & $0.040^{* * *}$ & -0.019 \\
& $(0.014)$ & $(0.032)$ \\
Switch towards A $\times$ Modelo AFP & $0.078^{* *}$ & $-0.072^{*}$ \\
& $(0.029)$ & $(0.036)$ \\
Switch towards E & $-0.037^{* * *}$ & $0.163^{* * *}$ \\
& $(0.010)$ & $(0.041)$ \\
Switch towards E $\times$ Modelo AFP & $-0.105^{* * *}$ & 0.053 \\
& $(0.037)$ & $(0.043)$ \\
\hline $\mathrm{N}$ & 225 & 227 \\
$R^{2}$ & 0.689 & 0.534 \\
\hline
\end{tabular}


Table 5: Cumulative porformance in the Chilean equity and bond markets around actual and placebo recommendations dates. Cumulative adjusted equity returns ("CARs") are calculated by subtracting the MSCI world market index return in Chilean pesos from the returns of Santiago's stock exchange selective equity index (IPSA). Cumulative bond returns ("CRs") are based on the Dow Jones LATixx Chile Government Bond Index produced by LVA Indices. Returns after recommendations to sell equity are multiplied by -1 to enable us to aggregate across recommendations to buy and sell equity. We consider the first 15 recommendations of FyF ("Actual Events"). Placebo dates are selected between July 2003 and March 2006 using a probit model where the dependent variable takes the value of one if the recommended fund is fund A and zero if it is fund E ("Placebo Events"). The probit model is estimated in-sample during the period from July 2011 to March 2014 and we then compute the out-of-sample probability of FyF recommending fund A or E. Starting from a recommendation to hold fund $\mathrm{A}$, we assume a change to fund $\mathrm{E}$ occurs whenever the probability goes below 25\%. If fund $\mathrm{E}$ is being recommended, we assume a change to fund A occurs whenever the probability goes above $75 \%$. The "Day" column indicates the event time taking as day 0 the day when the recommendation was sent for actual events and the counterfactual date for placebo events. For the actual events we average cumulative returns across the 15 recommendations and for the placebo experiment we average across 17 placebo events found in the pre-FyF sample. Standard errors are based on cross sectional t-tests. *** $p<0.01$, ** $p<0.05,{ }^{*} p<0.1$.

\begin{tabular}{|c|c|c|c|c|c|c|c|c|}
\hline \multirow{3}{*}{ Day } & \multicolumn{4}{|c|}{ Actual Events } & \multicolumn{4}{|c|}{ Placebo Events } \\
\hline & \multicolumn{2}{|c|}{ Equity Index } & \multicolumn{2}{|c|}{ Govt. Bond Index } & \multicolumn{2}{|c|}{ Equity Index } & \multicolumn{2}{|c|}{ Govt. Bond Index } \\
\hline & CAR & Std.Err. & CR & Std.Err. & CAR & Std.Err. & CR & Std.Err. \\
\hline 1 & $0.0106^{* * *}$ & $(0.0029)$ & 0.0000 & $(0.0005)$ & -0.0003 & $(0.0024)$ & 0.0000 & $(0.0003)$ \\
\hline 2 & $0.0112^{* * *}$ & $(0.0034)$ & -0.0001 & $(0.0006)$ & -0.0031 & $(0.0036)$ & -0.0006 & $(0.0004)$ \\
\hline 3 & $0.0122^{* *}$ & $(0.0053)$ & -0.0008 & $(0.0009)$ & -0.0028 & $(0.0030)$ & -0.0005 & $(0.0006)$ \\
\hline 4 & 0.0106 & $(0.0065)$ & -0.0009 & $(0.0009)$ & -0.0013 & $(0.0031)$ & -0.0009 & $(0.0006)$ \\
\hline 5 & 0.0058 & $(0.0058)$ & -0.0010 & $(0.0009)$ & 0.0051 & $(0.0032)$ & -0.0002 & $(0.0008)$ \\
\hline 6 & 0.0095 & $(0.0065)$ & -0.0007 & $(0.0010)$ & 0.0028 & $(0.0038)$ & -0.0001 & $(0.0007)$ \\
\hline 7 & 0.0076 & $(0.0065)$ & -0.0007 & $(0.0013)$ & 0.0012 & $(0.0046)$ & 0.0002 & $(0.0008)$ \\
\hline 8 & 0.0097 & $(0.0065)$ & -0.0014 & $(0.0015)$ & 0.0019 & $(0.0053)$ & 0.0001 & $(0.0008)$ \\
\hline 9 & 0.0107 & $(0.0081)$ & -0.0018 & $(0.0013)$ & 0.0009 & $(0.0057)$ & -0.0002 & $(0.0010)$ \\
\hline 10 & 0.0033 & $(0.0090)$ & -0.0023 & $(0.0016)$ & -0.0034 & $(0.0062)$ & -0.0007 & $(0.0011)$ \\
\hline 11 & 0.0012 & $(0.0080)$ & $-0.0033^{*}$ & $(0.0019)$ & -0.0057 & $(0.0071)$ & -0.0005 & $(0.0012)$ \\
\hline 12 & 0.0061 & $(0.0084)$ & -0.0029 & $(0.0021)$ & -0.0050 & $(0.0083)$ & -0.0004 & $(0.0013)$ \\
\hline 13 & 0.0064 & $(0.0100)$ & -0.0028 & $(0.0019)$ & -0.0037 & $(0.0094)$ & -0.0006 & $(0.0014)$ \\
\hline 14 & 0.0013 & $(0.0090)$ & -0.0030 & $(0.0021)$ & -0.0005 & $(0.0097)$ & -0.0004 & $(0.0014)$ \\
\hline 15 & -0.0042 & $(0.0105)$ & -0.0036 & $(0.0022)$ & 0.0029 & $(0.0095)$ & -0.0002 & $(0.0015)$ \\
\hline
\end{tabular}


Table 6: Time-series regressions of daily returns for Chilean equity and government bonds, from January 2010 to February 2014. The equity return is the return of Santiago's stock exchange selective equity index (IPSA) minus the return in pesos of the MSCI World Index. The government bond return is the return of the Dow Jones LATixx Chile Government Bond Index produced by LVA Indices. "Day $i$ " variables correspond to indicator variables that take the value of one if the day corresponds to the $i-t h$ day after a recommendation was sent. Sell and buy recommendations are restricted to have the same impact in absolute value. Day indicator variables are positive one when recommending to buy equity and negative one when recommending to sell equity. Control variables include the cumulative returns in each of the four previous weeks, the sums of the squared returns in the same weeks, the lagged $\mathrm{PE}$ ratio, the lagged 2- and 10-yr government bond yields, lagged inflation, the percentage change in the exchange rate the previous week, and the contemporaneous return in pesos of the MSCI World Index. PE is taken from Bloomberg and corresponds to the value reported 30 trading days earlier. Lagged inflation is measured as the inflation rate of the month corresponding to 30 trading days earlier. Standard errors are reported in parentheses. *** $p<0.01,{ }^{* *} p<0.05,{ }^{*} p<0.1$.

\begin{tabular}{lccccc}
\hline \multirow{2}{*}{ Variables } & \multicolumn{2}{c}{ Adjusted equity return } & & \multicolumn{2}{c}{ Government bond return } \\
\cline { 2 - 3 } \cline { 5 - 6 } & $(1)$ & $(2)$ & & $(3)$ & $(4)$ \\
\hline Day 1 & $0.0105^{* * *}$ & $0.0077^{* * *}$ & 0.0000 & -0.0000 \\
& $(0.0029)$ & $(0.0022)$ & & $(0.0004)$ & $(0.0004)$ \\
Day 2 & 0.0006 & -0.0006 & & -0.0001 & -0.0000 \\
& $(0.0029)$ & $(0.0023)$ & & $(0.0004)$ & $(0.0004)$ \\
Day 3 & 0.0010 & 0.0029 & & $-0.0007^{*}$ & -0.0005 \\
& $(0.0029)$ & $(0.0022)$ & & $(0.0004)$ & $(0.0004)$ \\
Day 4 & -0.0016 & -0.0012 & & -0.0001 & -0.0000 \\
& $(0.0029)$ & $(0.0022)$ & & $(0.0004)$ & $(0.0004)$ \\
Day 5 & $-0.0048^{*}$ & -0.0020 & & -0.0000 & 0.0002 \\
& $(0.0029)$ & $(0.0022)$ & $(0.0004)$ & $(0.0004)$ \\
\hline Controls & no & yes & no & yes \\
$\mathrm{N}$ & 1,038 & 1,009 & 1,038 & 1,009 \\
$R^{2}$ & 0.0162 & 0.4165 & 0.0032 & 0.1071 \\
\hline
\end{tabular}


Table 7: Time-series regressions of daily returns for Chilean equity from January 2010 to February 2014. The dependent variable in all panels is the return of Santiago's stock exchange selective equity index (IPSA) minus the return in pesos of the MSCI World Index. In columns (1) and (2) we separate the recommendations into early recommendations (recommendations 1-7) and late recommendations (recommendations 8-15). In columns (3) and (4) we separate the sample according to the direction of the recommended switch. In column (5) we include in our estimation all the recommendations that recommended partial switches between funds A, C and E (starting with recommendation 16 in Table 2). "Day $i$ " variables correspond to indicator variables that take the value of one if the day corresponds to the $i-t h$ day after an recommendation was sent. Sell and buy recommendations are restricted to have the same impact in absolute value (Day dummies are a positive one when recommending to buy equity and a negative one when recommending to sell equity). All regressions include as control variables the cumulative returns in each of the four previous weeks, the sums of the squared returns in the same weeks, the lagged PE ratio, the lagged 2- and 10-yr government bond yields, lagged inflation, the percentage change in the exchange rate the previous week, and the contemporaneous return in pesos of the MSCI World Index. PE is taken from Bloomberg and corresponds to the value reported 30 trading days earlier. Lagged inflation is measured as the inflation rate of the month corresponding to 30 trading days earlier. Standard errors are reported in parentheses. ${ }^{* * *} p<0.01,{ }^{* *} p<0.05,{ }^{*} p<0.1$.

\begin{tabular}{|c|c|c|c|c|c|}
\hline \multirow[t]{2}{*}{ Variables } & $\begin{array}{c}\text { First } \\
\text { subsample }\end{array}$ & $\begin{array}{c}\text { Second } \\
\text { subsample }\end{array}$ & $\begin{array}{c}\text { Sell } \\
\text { equity }\end{array}$ & $\begin{array}{l}\text { Buy } \\
\text { equity }\end{array}$ & $\begin{array}{c}\text { Expanded } \\
\text { sample }\end{array}$ \\
\hline & (1) & (2) & (3) & (4) & (5) \\
\hline \multirow[t]{2}{*}{ Day 1} & 0.0045 & $0.0101^{* * *}$ & 0.0048 & $0.0106^{* * *}$ & $0.0044^{* *}$ \\
\hline & $(0.0033)$ & $(0.0030)$ & $(0.0031)$ & $(0.0033)$ & $(0.0020)$ \\
\hline \multirow[t]{2}{*}{ Day 2} & -0.0026 & 0.0010 & 0.0023 & -0.0040 & -0.0025 \\
\hline & $(0.0033)$ & $(0.0031)$ & $(0.0031)$ & $(0.0033)$ & $(0.0020)$ \\
\hline \multirow[t]{2}{*}{ Day 3} & 0.0012 & 0.0043 & 0.0046 & 0.0008 & $0.0037^{*}$ \\
\hline & $(0.0033)$ & $(0.0031)$ & $(0.0031)$ & $(0.0033)$ & $(0.0020)$ \\
\hline \multirow[t]{2}{*}{ Day 4} & -0.0001 & -0.0021 & -0.0004 & -0.0019 & -0.0015 \\
\hline & $(0.0033)$ & $(0.0031)$ & $(0.0031)$ & $(0.0032)$ & $(0.0020)$ \\
\hline \multirow[t]{2}{*}{ Day 5} & 0.0019 & $-0.0054^{*}$ & -0.0013 & -0.0027 & 0.0009 \\
\hline & $(0.0033)$ & $(0.0031)$ & $(0.0031)$ & $(0.0032)$ & $(0.0020)$ \\
\hline $\mathrm{N}$ & 961 & 967 & 967 & 961 & 1,326 \\
\hline$R^{2}$ & 0.4210 & 0.4151 & 0.4054 & 0.4301 & 0.2263 \\
\hline
\end{tabular}


Table 8: Regressions of cumulative returns and turnover on FIP. In each event day (from day one up to day five), pooling across events, we run a regression of the cumulative return (turnover) on stock characteristics. FIP is the flow induced pressure measured as the signed flow into the aggregate fund $\mathrm{A}$ in the pension fund system times the weight of each stock in fund A's portfolio in the previous month, and over the market capitalization of the stock in the previous month. We use the raw FIP for Panel A and the absolute value of FIP for Panel B. Other controls include size (log of market cap), the book-to-market ratio, and momentum. All regressions include event fixed effects. Standard errors are reported in parentheses. *** $p<0.01,{ }^{* *} p<0.05,{ }^{*} p<0.1$.

\begin{tabular}{lccccc}
\hline \multicolumn{5}{c}{ Panel A. Dependent variable: cumulative return to day \# } \\
& $(1)$ & $(2)$ & $(3)$ & $(4)$ & $(5)$ \\
\hline \multirow{2}{*}{ FIP } & 0.839 & $1.870^{*}$ & $3.399^{* *}$ & 2.297 & 1.017 \\
& $(0.815)$ & $(1.134)$ & $(1.440)$ & $(1.605)$ & $(1.870)$ \\
ln Mkt Cap & 0.001 & -0.001 & -0.001 & -0.001 & -0.002 \\
& $(0.001)$ & $(0.001)$ & $(0.001)$ & $(0.001)$ & $(0.002)$ \\
B/M & 0.000 & -0.003 & -0.003 & -0.003 & -0.002 \\
& $(0.001)$ & $(0.002)$ & $(0.002)$ & $(0.002)$ & $(0.003)$ \\
MOM & -0.005 & -0.005 & -0.002 & -0.002 & -0.001 \\
& $(0.003)$ & $(0.005)$ & $(0.006)$ & $(0.006)$ & $(0.007)$ \\
\hline $\mathrm{N}$ & 471 & 472 & 471 & 471 & 471 \\
$R^{2}$ & 0.355 & 0.288 & 0.315 & 0.225 & 0.214 \\
\hline
\end{tabular}

Panel B. Dependent variable: cumulative turnover to day \#

\begin{tabular}{lccccc} 
& $(1)$ & $(2)$ & $(3)$ & $(4)$ & $(5)$ \\
\hline Abs(FIP) & 0.063 & 0.154 & 0.616 & $0.844^{* *}$ & $0.905^{*}$ \\
& $(0.255)$ & $(0.324)$ & $(0.392)$ & $(0.415)$ & $(0.500)$ \\
ln Mkt Cap & -0.000 & -0.000 & -0.000 & -0.000 & -0.000 \\
& $(0.000)$ & $(0.000)$ & $(0.000)$ & $(0.000)$ & $(0.000)$ \\
B/M & -0.000 & -0.000 & $-0.001^{* *}$ & $-0.002^{* * *}$ & $-0.002^{* * *}$ \\
& $(0.000)$ & $(0.000)$ & $(0.001)$ & $(0.001)$ & $(0.001)$ \\
MOM & -0.000 & -0.001 & -0.001 & -0.001 & -0.001 \\
& $(0.001)$ & $(0.001)$ & $(0.002)$ & $(0.002)$ & $(0.002)$ \\
\hline $\mathrm{N}$ & 471 & 472 & 471 & 471 & 471 \\
$R^{2}$ & 0.033 & 0.043 & 0.054 & 0.062 & 0.063 \\
\hline
\end{tabular}


Table 9: Excess volatility. The dependent variable is the monthly return volatility of the stocks in the sample. FIP is defined as the absolute value of the flow to fund A in month $t$ times the weight of stock $i$ held in fund A's portfolio in month $t-1$ divided by the market capitalization of stock $i$. Momentum is the cumulated return between months $t-12$ and $t-2$. Market cap is the log of the market value of the stocks in Santiago's stock exchange measured on June of each year. B/M is book to market ratio measured in December of the previous year. Turnover corresponds to the average turnover of the past 12 months. Ret Vol is last month's return volatility. Standard errors are clustered by month, and regressions include stock fixed effects and time fixed effects. ${ }^{* * *} p<0.01,{ }^{* *} p<0.05,{ }^{*} p<0.1$.

\begin{tabular}{lcccc}
\hline & $(1)$ & $(2)$ & $(3)$ & $(4)$ \\
\hline $\operatorname{Abs}(\mathrm{FIP})$ & $1.506^{* * *}$ & $1.798^{* * *}$ & $0.773^{* *}$ & $0.613^{*}$ \\
& $(0.368)$ & $(0.407)$ & $(0.292)$ & $(0.359)$ \\
$\ln$ Mkt Cap & & -0.000 & -0.000 & $-0.002^{*}$ \\
& & $(0.000)$ & $(0.000)$ & $(0.001)$ \\
$\mathrm{B} / \mathrm{M}$ & & $-0.001^{* * *}$ & -0.000 & -0.001 \\
& & $(0.000)$ & $(0.000)$ & $(0.001)$ \\
$\mathrm{MOM}$ & & $0.002^{* *}$ & 0.001 & -0.001 \\
& & $(0.001)$ & $(0.001)$ & $(0.001)$ \\
Turnover & & & $0.043^{* * *}$ & 0.011 \\
& & & $(0.015)$ & $(0.019)$ \\
Ret Vol & & & $0.476^{* * *}$ & $0.206^{* * *}$ \\
& time & time & time & time \\
\hline Fixed effects & & & & stock \\
N & 1,755 & 1,688 & 1,687 & 1,687 \\
$R^{2}$ & 0.224 & 0.256 & 0.452 & 0.554 \\
Number of cross-sections & 48 & 48 & 48 & 48 \\
\hline
\end{tabular}


Table 10: Monthly cash holding regression. We regress monthly cash holdings (in percentage of total fund asset value) of different AFPs on FyF recommendation indicator variables. The recommendation dummy is one during a month when the recommendation is a switch towards A; negative one when the recommendation is a switch towards E; and zero otherwise. Although not reported, the regressions in columns corresponding to "All AFPs" include AFP fixed effects.

\begin{tabular}{|c|c|c|c|c|c|c|}
\hline & \multicolumn{2}{|c|}{ Fund A } & \multicolumn{2}{|c|}{ Fund E } & \multicolumn{2}{|c|}{ Funds B/C/D } \\
\hline & All AFPs & Modelo & All AFPs & Modelo & All AFPs & Modelo \\
\hline Intercept & $\begin{array}{l}2.091^{* * *} \\
(0.434)\end{array}$ & $\begin{array}{c}1.224^{* *} \\
(0.637)\end{array}$ & $\begin{array}{l}7.562^{* * *} \\
(2.312)\end{array}$ & $\begin{array}{l}14.404^{* * *} \\
(2.189)\end{array}$ & $\begin{array}{l}8.203^{* * *} \\
(0.430)\end{array}$ & $\begin{array}{l}11.474^{* * *} \\
(1.163)\end{array}$ \\
\hline Trend & $\begin{array}{c}0.043^{* *} \\
(0.018)\end{array}$ & $\begin{array}{l}0.094^{* * *} \\
(0.030)\end{array}$ & $\begin{array}{l}0.477^{* * *} \\
(0.141)\end{array}$ & $\begin{array}{c}0.023 \\
(0.102)\end{array}$ & $\begin{array}{c}-0.092^{* * *} \\
(0.017)\end{array}$ & $\begin{array}{c}-0.177^{* * *} \\
(0.055)\end{array}$ \\
\hline FyF Recommendation & $\begin{array}{c}0.497^{* *} \\
(0.255)\end{array}$ & $\begin{array}{c}0.971^{*} \\
(0.540)\end{array}$ & $\begin{array}{c}-0.827^{* *} \\
(0.422)\end{array}$ & $\begin{array}{r}-1.000 \\
(1.851)\end{array}$ & $\begin{array}{r}-0.089 \\
(0.171)\end{array}$ & $\begin{array}{r}-0.099 \\
(0.994)\end{array}$ \\
\hline $\mathrm{N}$ & 216 & 36 & 216 & 36 & 648 & 108 \\
\hline$R^{2}$ & 0.105 & 0.298 & 0.357 & 0.010 & 0.050 & 0.091 \\
\hline
\end{tabular}

